\title{
Metallurgical Model of Diffusible Hydrogen and Non-Metallic Slag Inclusions in Underwater Wet Welding of High-Strength Steel
}

\author{
Sergey G. Parshin ${ }^{1, *(\mathbb{C})}$, Alexey M. Levchenko ${ }^{2}$ and Alexey S. Maystro ${ }^{1}$ \\ 1 Department of Welding and Laser Technologies, Peter the Great St. Petersburg Polytechnic University, \\ 187015 St. Petersburg, Russia; maystro@spbstu.ru \\ 2 Department of Underwater Welding and Technologies, Educational Scientific and Technical Center "Svarka", \\ 187015 St. Petersburg, Russia; schweissen@mail.ru \\ * Correspondence: parshin@spbstu.ru; Tel.: +7-812-552-63-55
}

Received: 20 October 2020; Accepted: 6 November 2020; Published: 10 November 2020

check for updates

\begin{abstract}
High susceptibility to cold cracking induced by diffusible hydrogen and hydrogen embrittlement are major obstacles to greater utilization of underwater wet welding for high-strength steels. The aim of the research was to develop gas-slag systems for flux-cored wires that have high metallurgical activity in removal of hydrogen and hydroxyl groups. Thermodynamic modeling and experimental research confirmed that a decrease in the concentration of diffusible hydrogen can be achieved by reducing the partial pressure of hydrogen and water vapor in the vapor-gas bubble and by increasing the hydroxyl capacity of the slag system in metallurgical reactions leading to hydrogen fluoride formation and ionic dissolution of hydroxyl groups in the basic fluorine-containing slag of a $\mathrm{TiO}_{2}-\mathrm{CaF}_{2}-\mathrm{Na}_{3} \mathrm{AlF}_{6}$ system.
\end{abstract}

Keywords: underwater wet welding; diffusible hydrogen; slag inclusions; flux-cored wire

\section{Introduction}

Underwater wet welding is a welding technique commonly used for the construction and repair of ocean-going vessels, oil and gas platforms, and offshore wind turbines. The load-bearing structures of such vessels and installations are often made of high-strength steels [1,2], which pose considerable challenges to welders and the welding processes to obtain the welds exhibiting high levels of strength, ductility, and impact toughness [3,4]. A further issue is that underwater wet welding is susceptible to weld defects like hydrogen-assisted cold cracking, porosity, slag inclusions, and delayed hydrogen embrittlement [5-10]. Consequently, underwater wet welding has found only limited use for critical applications, which requires further study of the mechanism of the appearance of defects.

The appearance of defects during underwater welding is associated with the formation of diffusible hydrogen, active oxygen, and slag in the welding zone [11]. In underwater wet welding, the welding occurs in a vapor-gas bubble [12-14] in which the hydrogen content reaches 85-96\% [15]. When welding with coated electrodes and flux-cored rutile wire, the vapor-gas bubble comprises 93-98\% $\mathrm{H}_{2}, 1.5-6 \% \mathrm{CO}$, and $0.5-2 \% \mathrm{CO}_{2}$ [16]. Hydrogen from the vapor-gas bubble can be absorbed into the liquid weld, which is the major cause of porosity in underwater wet welding. The gas composition of pores in the weld consists of $62-82 \mathrm{wt} . \% \mathrm{H}_{2}, 11-24 \mathrm{wt} . \% \mathrm{CO}$, and 4-6 wt.\% $\mathrm{CO}_{2}$, depending on the composition of the electrode coating and the welding parameters used [17].

Before dissolution of hydrogen atoms in the liquid weld pool, dissociation of $\mathrm{H}_{2} \mathrm{O}$ and $\mathrm{H}_{2}$ occurs [18]. At the arc temperature, water $\left(\mathrm{H}_{2} \mathrm{O}\right)$ dissociates according to the following reaction:

$$
\mathrm{H}_{2} \mathrm{O}=\mathrm{H}_{2}+0.5 \mathrm{O}_{2}-260 \mathrm{~kJ}(\text { at } 6000 \mathrm{~K})
$$




$$
\lg K_{q}=\lg \frac{P_{\mathrm{H} 2} P_{\mathrm{O} 2} 0.5}{P_{\mathrm{H} 2 \mathrm{O}}}
$$

where $K_{q}$ is the reaction equilibrium constant, and $P_{\mathrm{H} 2}, P_{\mathrm{O} 2}$, and $P_{\mathrm{H} 2 \mathrm{O}}$ are the partial pressure (Pa) of $\mathrm{H}_{2}, \mathrm{O}_{2}$, and $\mathrm{H}_{2} \mathrm{O}$, respectively.

With further heating of the gas mixture, endothermic reactions of dissociation of the $\mathrm{H}_{2}$ molecules and ionization of the $\mathrm{H}$ atoms occur.

$$
\begin{gathered}
\mathrm{H}_{2}=\mathrm{H}+\mathrm{H}-463.1 \mathrm{~kJ} \\
\mathrm{H}_{2}=\mathrm{H}+\mathrm{H}^{+}+\mathrm{e}-1746.7 \mathrm{~kJ}
\end{gathered}
$$

Dissolution of molecular hydrogen in the weld pool increases with growth in the partial pressure of the components of the gas mixture according to Sieverts' law.

$$
[\mathrm{H}]=K_{s} \sqrt{P_{\mathrm{H} 2}}
$$

where $[\mathrm{H}]$ is the hydrogen content in the weld in wt.\%, $P_{\mathrm{H} 2}$ is the partial pressure of molecular hydrogen in the gas phase, and $K_{s}$ is the solubility constant.

With increases in the immersion depth, the pressure in the vapor-gas bubble increases by about $0.1 \mathrm{MPa}$ for every $10 \mathrm{~m}$ of immersion depth, and at a depth of $50 \mathrm{~m}$ the total pressure reaches $0.6 \mathrm{MPa}$. The increase in pressure promotes the dissolution of hydrogen in the weld pool and thus porosity increases [19-23].

One mechanism for diffusible hydrogen reduction is a decrease in the hydrogen partial pressure in the vapor-gas bubble atmosphere, for example, by dissociation of carbonates and fluorides, namely $\mathrm{Na}_{2} \mathrm{CO}_{3}, \mathrm{NaF}, \mathrm{CaCO}_{3}, \mathrm{CaF}_{2}, \mathrm{MgCO}_{3}$, and $\mathrm{MgF}_{2}$, in the flux-cored wire. To reduce porosity, carbonates $\mathrm{CaCO}_{3}$ and $\mathrm{MgCO}_{3}$ can be added into the electrode coatings. The carbonates dissociate in the vapor-gas bubble with the formation of $\mathrm{CO}_{2}$ and $\mathrm{CO}$, which reduces the hydrogen partial pressure above the weld pool [24].

A second mechanism for hydrogen reduction is via the chemical reaction of hydrogen and fluorine with formation of $\mathrm{HF}$ compounds in reactions with fluorides $\mathrm{NaF}, \mathrm{CaF}_{2}, \mathrm{MgF}_{2}, \mathrm{AlF}_{3}$, etc. [25,26]. A linear decrease in the content of diffusible hydrogen $[\mathrm{H}]$ in the weld metal occurs with increases in the content of $\mathrm{CaF}_{2}$ from 0 to $86 \mathrm{wt}$.\%. Increasing $\mathrm{CaF}_{2}$ is a more effective approach for reducing hydrogen than adding $\mathrm{CaCO}_{3}$ to the electrode coating. For example, $[\mathrm{H}]$ content in the weld is $54 \mathrm{~cm}^{3} / 100 \mathrm{~g}$ when adding $20 \mathrm{wt} . \% \mathrm{CaCO}_{3}$ to the electrode coating, and when adding $20 \mathrm{wt} . \% \mathrm{CaF}_{2}$, the $[\mathrm{H}]$ content decreases to $39 \mathrm{~cm}^{3} / 100 \mathrm{~g}$ [26].

A third mechanism for hydrogen reduction is an increase of the oxidation potential of the weld pool and solubility of water vapor and $\mathrm{OH}$ hydroxyl groups in the liquid slag, in particular, by the addition of hematite $\mathrm{Fe}_{2} \mathrm{O}_{3}$ with a density of $5.3 \mathrm{~g} / \mathrm{cm}^{3}$ [9]. Hematite $\mathrm{Fe}_{2} \mathrm{O}_{3}$ decomposes under high-temperature conditions with the formation of wüstite $\mathrm{FeO}$ in the molten slag, which increases the basicity index of the slag; in addition, $\mathrm{FeO}$ oxidizes the weld pool, which inhibits dissolution of diffusible hydrogen in the weld pool. However, an increase in the oxidizing potential of the slag and the atmosphere of the vapor-gas bubble leads to slag nonmetallic inclusions and oxidation of alloying elements [27-30], which reduces the mechanical properties of the welds $[9,31]$.

The slag basicity index BI is calculated as follows [32]:

$$
\mathrm{BI}=\frac{\mathrm{CaO}+\mathrm{MgO}+\mathrm{BaO}+\mathrm{CaF}_{2}+\mathrm{Na}_{2} \mathrm{O}+\mathrm{K}_{2} \mathrm{O}+0.5(\mathrm{FeO}+\mathrm{MnO})}{\mathrm{SiO}_{2}+0.5\left(\mathrm{Al}_{2} \mathrm{O}_{3}+\mathrm{TiO}_{2}+\mathrm{ZrO}_{2}\right)}
$$


The hydroxyl capacity of a $\mathrm{C}_{\mathrm{OH}}$ slag system is determined according to the following equation:

$$
C_{\mathrm{OH}}=\frac{\% \mathrm{H}_{2} \mathrm{O}}{\sqrt{P_{\mathrm{H}_{2} \mathrm{O}} / P^{0}}}
$$

where $\mathrm{H}_{2} \mathrm{O}$ is the content of water vapor in the slag in wt. $\%, P_{\mathrm{H} 2 \mathrm{O}}$ is the partial pressure of water vapor in the gas phase above the molten slag in the equilibrium state, and $P^{0}$ is the atmospheric pressure [33]. A ratio for the hydroxyl capacity of $C_{\mathrm{OH}}$ slag has been proposed in [34,35] as follows:

$$
\log C_{\mathrm{OH}}=12.04-32.63 \Lambda+32.71 \Lambda^{2}-6.62 \Lambda^{3}
$$

An increase in the basicity index of the slag and hydroxyl capacity can be achieved by adding $\mathrm{CaF}_{2}$ and cryolite $\mathrm{Na}_{3} \mathrm{AlF}_{6}$, which decrease the melting point, viscosity, hydrogen permeability, and density of the slag system [36-41]. The increase in slag basicity and the presence of ion $\mathrm{F}^{-}$elevate the solubility of water vapor and promote the ionic binding of the hydrogen atom in $\mathrm{OH}$ hydroxyl groups, which leads to a decrease in the content of diffusible hydrogen [42]. The subsequent binding of hydroxyl groups $\mathrm{OH}$ is possible in the polymerization of $\mathrm{AlF}_{6}{ }^{3-}$ and $\mathrm{AlF}_{4}{ }^{-}$anions and the formation of clusters with the bonds -F-H-F- and -Al-O-Al- [43-45].

Simultaneous implementation of all three mechanisms for the decrease of diffusible hydrogen in underwater wet welding is possible by creating a low-density slag system based on $\mathrm{TiO}_{2}-\mathrm{CaF}_{2}-\mathrm{Na}_{3} \mathrm{AlF}_{6}$. It is known that water vapor dissolves in acidic and basic slags following the following ionic reactions [46-48]:

$$
\begin{gathered}
-\mathrm{Si}-\mathrm{O}-\mathrm{Si}-+\mathrm{H}_{2} \mathrm{O}=2(-\mathrm{Si}-\mathrm{OH}-) \text { (acidic slag) } \\
\mathrm{O}^{0}+\mathrm{H}_{2} \mathrm{O}=2(\mathrm{OH})(\text { acidic slag }) \\
2(-\mathrm{Si}-\mathrm{O}-\mathrm{Si}-)+\mathrm{Fe}^{2+}+\mathrm{H}_{2} \mathrm{O}=-\mathrm{Si}-\mathrm{O}-\mathrm{Si}+2\left(\mathrm{OH}^{-}\right)+\mathrm{Fe}^{2+} \text { (basic slag) } \\
2(-\mathrm{Si}-\mathrm{O}-\mathrm{Si}-)+\mathrm{Fe}^{2+}+\mathrm{H}_{2} \mathrm{O}=2(-\mathrm{Si}-\mathrm{OH}-)+\mathrm{O}^{2-}+\mathrm{Fe}^{2+} \text { (basic slag) } \\
\mathrm{H}_{2} \mathrm{O}+2 \mathrm{O}^{-}=\left(\mathrm{O}^{2-}\right)+2(\mathrm{OH})(\text { highly basic slag) } \\
\mathrm{H}_{2} \mathrm{O}+2 \mathrm{O}^{-}=\left(\mathrm{O}^{0}\right)+2\left(\mathrm{OH}^{-}\right) \text {(highly basic slag) } \\
\mathrm{H}_{2} \mathrm{O}+\mathrm{O}^{2-}=2\left(\mathrm{OH}^{-}\right)(\text {highly basic slag) }
\end{gathered}
$$

The transition of atomic hydrogen into the weld pool and the formation of diffusible hydrogen $[\mathrm{H}]$ occurs according to the following ionic equations (proposed by S.G. Parshin):

$$
\begin{gathered}
\left(\mathrm{H}^{+}\right)+\mathrm{e}^{-}+\left(\mathrm{O}^{2-}\right)+\left(\mathrm{Fe}^{2+}\right)=[\mathrm{Fe}]+[\mathrm{O}]+[\mathrm{H}] \\
\left(\mathrm{OH}^{-}\right)+\mathrm{e}^{-}+\left(\mathrm{Fe}^{2+}\right)=[\mathrm{FeO}]+[\mathrm{H}]
\end{gathered}
$$

In the molten fluoride slags, an ionic reaction binds hydrogen with the formation of anions $\left(\mathrm{OH}^{-}\right)$ and gaseous compound HF个. Thus, the formation of anions $\left(\mathrm{OH}^{-}\right)$, the binding of hydrogen in $\mathrm{HF}$, and formation of network clusters of $\mathrm{AlF}_{6}{ }^{3-}$ and $\mathrm{AlF}_{4}{ }^{-}$anions can energetically hinder the transition of atomic hydrogen into the weld pool and the formation of diffusible hydrogen $[\mathrm{H}]$.

The aim of the research was to develop a gas-slag system for a flux-cored wire for underwater wet welding that has high metallurgical activity and reduces diffusible hydrogen and non-metallic slag inclusions by removing hydrogen and hydroxyl in the vapor-gas bubble atmosphere and increasing the solubility of water vapor in the slag phase. 


\section{Materials and Methods}

Samples of API X70 pipeline steel (CHTPZ, Chelyabinsk, Russia) with bainitic microstructure having dimensions of $300 \mathrm{~mm} \times 200 \mathrm{~mm} \times 21.3 \mathrm{~mm}$ was welded underwater in butt and lap joint configurations, as shown in Figure 1.
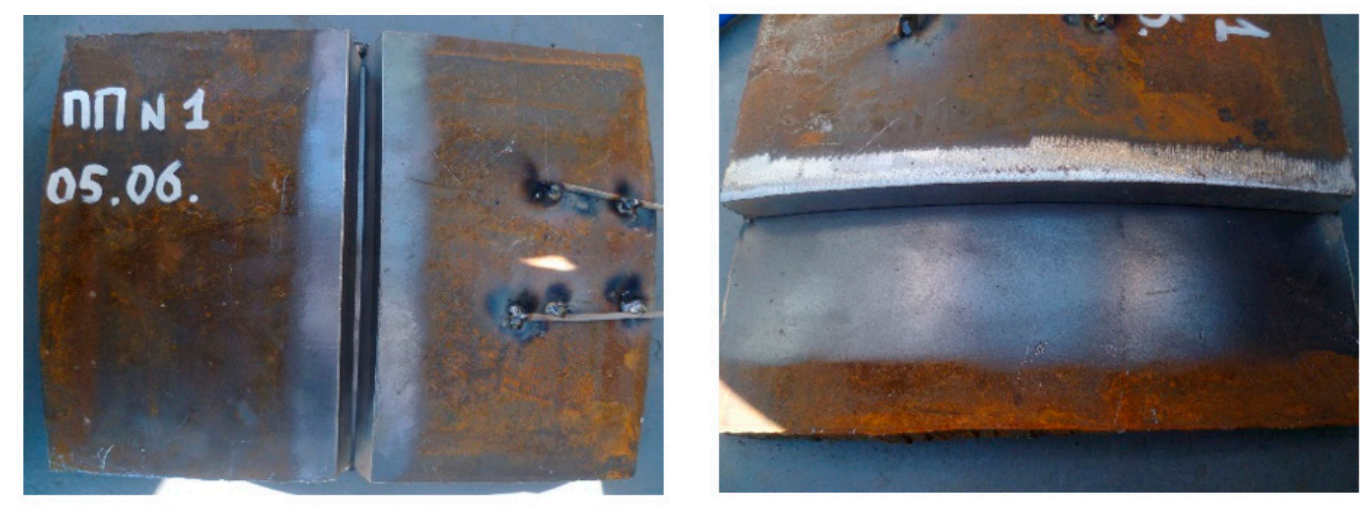

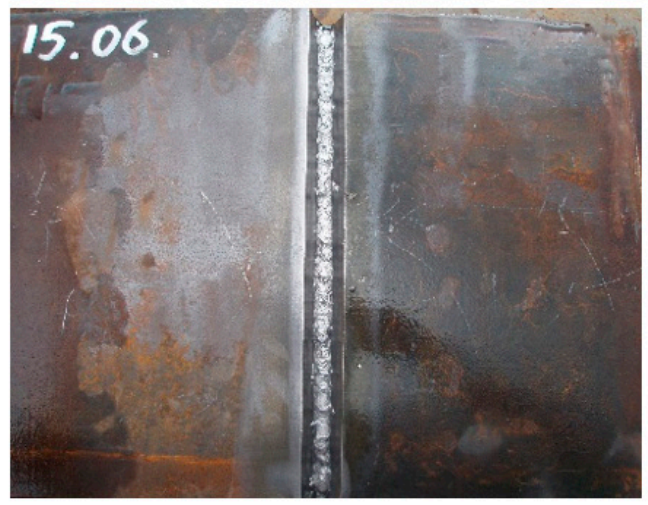

(a)

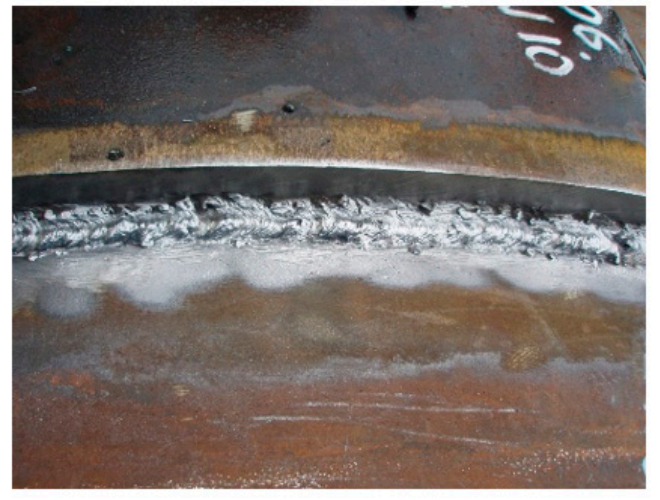

(b)

Figure 1. Assembly and root pass welding of (a) butt and (b) lap joints.

Mechanized underwater wet welding was performed by divers at a depth of $12 \mathrm{~m}$ using a Neptun-4 submersible (Paton Institute of Electric Welding, Kiev, Ukraine). Flux-cored wires were used of type PPS-AN1 (Paton Institute of Electric Welding, Kiev, Ukraine) $\left(\mathrm{TiO}_{2}-\mathrm{Fe}_{2} \mathrm{O}_{3}-\mathrm{MnO}\right.$-iron powder composition) and PPS-APL2 (Educational Scientific and Technical Center "Svarka", St. Petersburg, Russia) ( $\mathrm{TiO}_{2}-\mathrm{CaF}_{2}-\mathrm{Na}_{3} \mathrm{AlF}_{6}-\mathrm{MnO}$-iron powder composition). The wires had a diameter of $1.6 \mathrm{~mm}$ and the rutile electrodes E7014 and UW/CS-1 (Broco, ON, USA) ( $\mathrm{TiO}_{2}-\mathrm{CaCO}_{3}-\mathrm{SiO}_{2}-\mathrm{Al}_{2} \mathrm{O}_{3}-\mathrm{MnO}-\mathrm{iron}$ powder composition) were $3.2 \mathrm{~mm}$ in diameter. Welding parameters are shown in Table 1.

Table 1. Welding parameters of underwater wet welding.

\begin{tabular}{cccc}
\hline Welding Consumables & Voltage, $\mathbf{V}$ & Current, A & Wire Feed Rate, $\mathbf{m} / \mathbf{m i n}$ \\
\hline UW/CS-1 electrode & $37.5-42.5$ & $135-175$ & - \\
\hline $\begin{array}{c}\text { PPS-AN1 flux-cored wire } \\
\left(\mathrm{TiO}_{2}-\mathrm{Fe}_{2} \mathrm{O}_{3}\right)\end{array}$ & $37.5-43.5$ & $120-300$ & 4 \\
\hline $\begin{array}{c}\text { PPS-APL2 flux-cored wire } \\
\left(\mathrm{TiO}_{2}-\mathrm{CaF}_{2}-\mathrm{Na}_{3} \mathrm{AlF}_{6}\right)\end{array}$ & $40-45$ & $100-240$ & 4 \\
\hline
\end{tabular}


Mechanical tests were conducted in compliance with GOST 6996-66 using a Super L60 machine (Tinius Olsen, Horsham, PA, USA), a PH450 pendulum impact test system (Walter + Bai AG, Löhningen, Switzerland), and an EMCOTEST DuraScan-20 hardness tester (EMCO-TEST PrufmaSchinen GmbH, Kuchl, Austria). The chemical composition was determined with a Bruker Q4 TASMAN optical emission spectrometer (Bruker, Karlsruhe, Germany). A Zeiss Axiovert 200 MAT microscope (Carl Zeiss AG, Oberkochen, Germany) was used to analyze the microstructure, and an ERESCO 42M X-ray unit (GE Sensing and Inspection Technologies GmbH, Ahrensburg, Germany) was used for X-ray testing in compliance with GOST 7512-82. Research of the vapor-gas bubble formation was performed by the shadow method with a laser system and Phantom VEO 710L high-speed camera (Vision Research, Wayne, NJ, USA) with a frequency of $8000 \mathrm{~Hz}$. Diffusible hydrogen content was determined by the vacuum method according to GOST 34061-2017 (ISO 3690: 2012) using an accelerated method [49] with automatic bead welding in water at the depth of $0.8 \mathrm{~m}$. Thermodynamic calculations were performed using FactSage (CRCT, Montreal, Canada) and Terra (Bauman Moscow State Technical University, Moscow, Russia) and were based on thermodynamic data of individual substances [50].

\section{Results and Discussion}

Underwater wet welding with a self-shielded flux-cored wire occurs in a vapor-gas bubble formed during dissociation of water. The welding arc consists of a central zone (arc column), a boundary zone around the arc column, and a molecular layer, in which water vapor dissociates. A proposed model of underwater wet welding using flux-cored wire is shown in Figure 2.

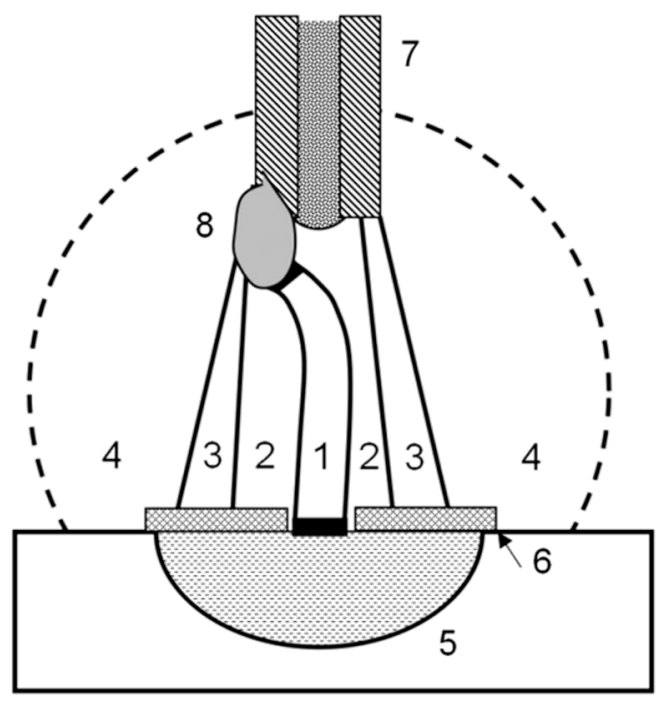

(a)

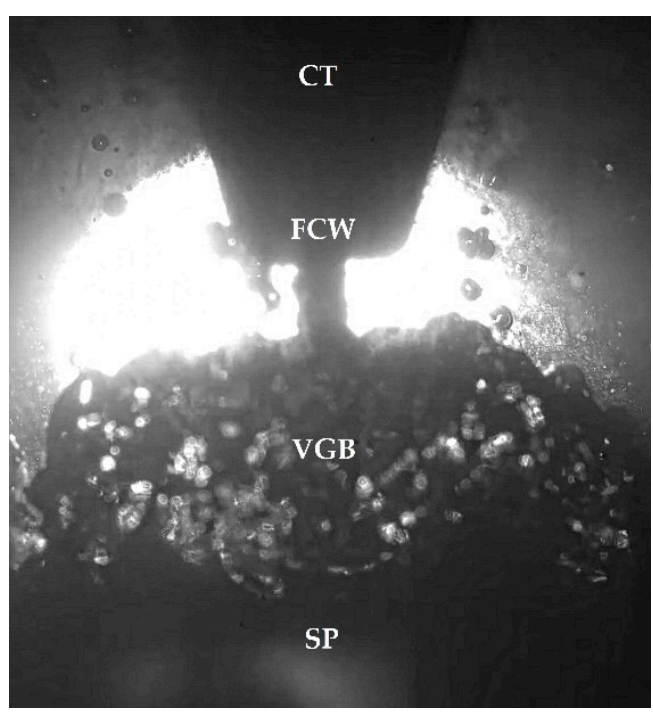

(b)

Figure 2. Arc model in underwater wet welding (a): 1-arc column; 2-arc boundary; 3-molecular layer of dissociation around the arc boundary; 4-vapor-gas bubble; 5-weld pool; 6-liquid slag; 7-flux-cored wire; 8-drop; (b) vapor-gas bubble shadow photo in flux-cored underwater wet arc welding: CT—contact tube; FCW—flux-cored wire; VGB—vapor-gas bubble; SP—steel plate (proposed by S.G. Parshin).

The formation of a vapor-gas bubble includes several phases: nucleation, volume expansion with the pulsations (or growth), and collapse, as shown in Figure 3. 


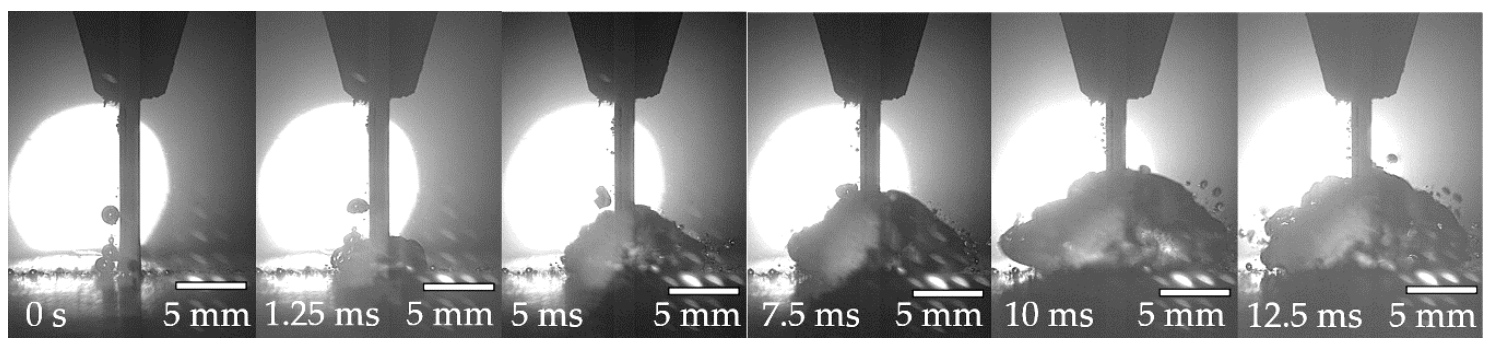

(a)

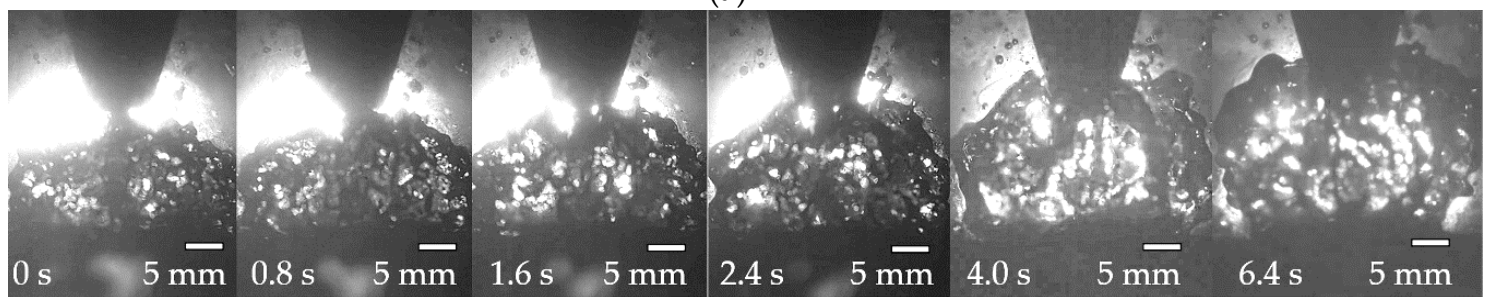

(b)

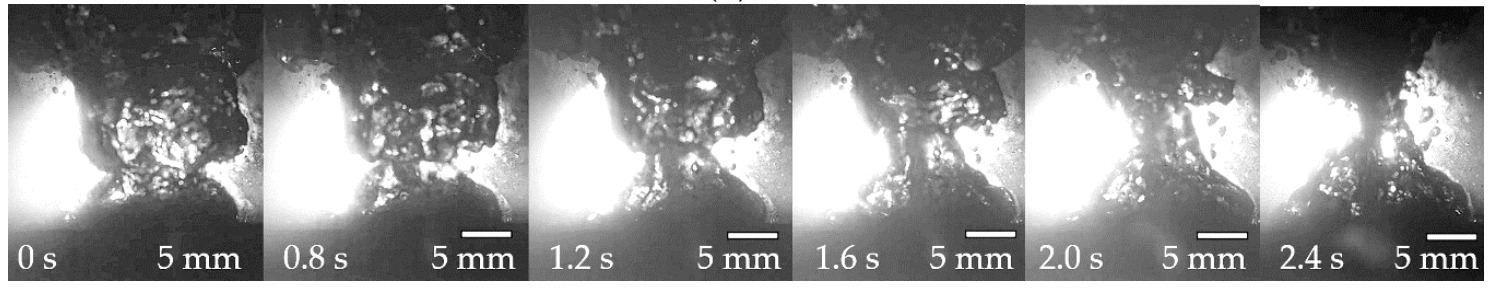

(c)

Figure 3. Formation of a vapor-gas bubble: (a) nucleation phase; (b) volume expansion phase; (c) collapse phase.

A detailed model of metallurgical processes in underwater wet welding is shown in Figure 4.

\begin{tabular}{|c|c|}
\hline Vapor-gas bubble & $\mathrm{H}_{2} \mathrm{O}_{\text {liquid }} \leftrightarrows \mathrm{H}_{2} \mathrm{O}_{\text {vapor }}-\mathrm{Q}$ \\
\hline Evaporation & $\mathrm{H}_{2} \mathrm{O}_{\text {vapor }} \leftrightarrows \mathrm{H}_{2}+0.5 \mathrm{O}_{2}-\mathrm{Q}$ \\
\hline Dissociation & $\mathrm{H}_{2} \leftrightarrows \mathrm{H}+\mathrm{H}-\mathrm{Q}$ \\
\hline Ionization & $\mathrm{H}_{2} \leftrightarrows \mathrm{H}+\mathrm{H}^{+}+\mathrm{e}^{-}-\mathrm{Q}$ \\
\hline Adsorption & $\mathrm{H}_{2} \mathrm{O}_{\text {vapor }}+\left(\mathrm{O}^{2-}\right) \leftrightarrows 2\left(\mathrm{OH}^{-}\right) \quad \mathrm{H}^{-} \mathrm{H}^{+} \quad \mathrm{H}_{2} \mathrm{O}_{\text {vapor }}+\left(\mathrm{F}^{-}\right) \leftrightarrows\left(\mathrm{OH}^{-}\right)+\mathrm{HF} \uparrow$ \\
\hline Liquid slag & $(\mathrm{H}) \leftrightarrows\left(\mathrm{H}^{+}\right)+\mathrm{e}^{-} \quad(\mathrm{H})\left(\mathrm{H}^{+}\right) \quad\left(\mathrm{CaF}_{2}\right) \leftrightarrows\left(\mathrm{Ca}^{2+}\right)+2\left(\mathrm{~F}^{-}\right)$ \\
\hline Dissociation & $\left.\left(\mathrm{H}^{+}\right)+\left(\mathrm{O}^{2-}\right) \leftrightarrows\left(\mathrm{OH}^{-}\right) \quad\left(\mathrm{Na}_{3} \mathrm{AlF}_{6}\right) \leftrightarrows\left(3 \mathrm{Na}^{+}\right)+\mathrm{AlF}_{6}{ }^{3-}\right)$ \\
\hline Ionic dissolution & $\begin{aligned}\left(\mathrm{H}^{+}\right)+\left(\mathrm{F}^{-}\right)=\mathrm{HF} \uparrow & \left(\mathrm{TiO}_{2}\right) \leftrightarrows\left(\mathrm{Ti}^{4+}\right)+2\left(\mathrm{O}^{2-}\right) \\
(\mathrm{FeO}) & \leftrightarrows\left(\mathrm{Fe}^{2+}\right)+\left(\mathrm{O}^{2-}\right)\end{aligned}$ \\
\hline Slag-metal interface & $\left(\mathrm{Fe}^{2+}\right)+\left(\mathrm{O}^{2-}\right)$ \\
\hline Ionic transition layer & $-i \uparrow$ \\
\hline Weld pool & \\
\hline Absorption & \\
\hline Solid m & \\
\hline
\end{tabular}

Figure 4. Model of metallurgical processes in underwater wet welding in vapor-gas bubble, liquid slag, and liquid weld pool (proposed by S.G. Parshin). 
In the molten slag occur the electrochemical interactions between $\mathrm{OH}^{-}$hydroxyl and $\mathrm{AlF}_{6}{ }^{3-}$ and $\mathrm{AlF}_{4}{ }^{-}$anions with the formation of bonds -F-H-F- and -Al-O-Al-, as shown in Figure 5.

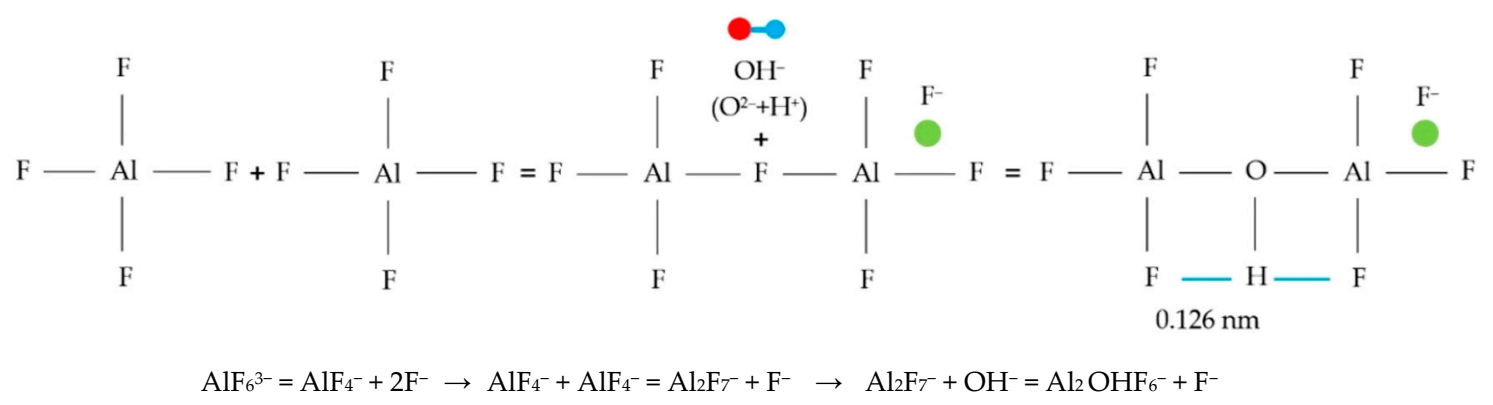

Figure 5. Electrochemical model of $\mathrm{OH}$ hydroxyl binding with the formation of network clusters in the interaction of $\mathrm{AlF}_{4}{ }^{-}$ions (proposed by S.G. Parshin).

As a result of water dissociation and ionization of molecules, the atmosphere of the vapor-gas bubble consists of a gas mixture of a complex phase composition with high metallurgical activity in reactions with the metal of the molten weld pool, as shown in Figure 6.

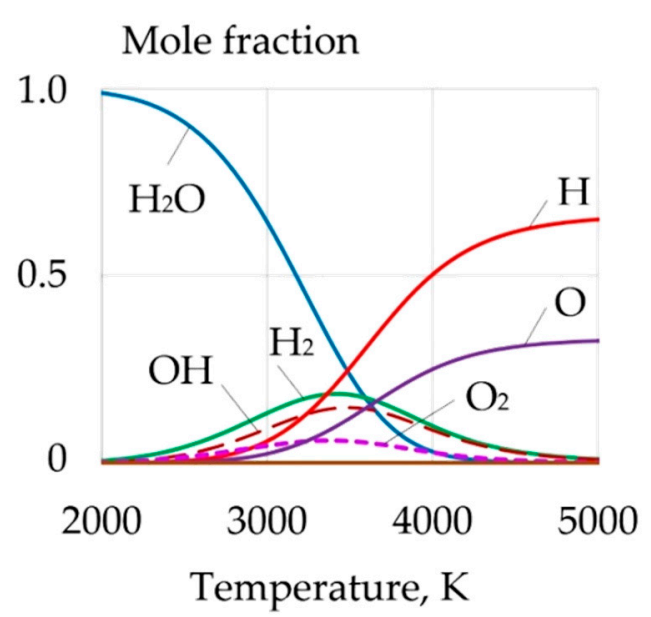

(a)

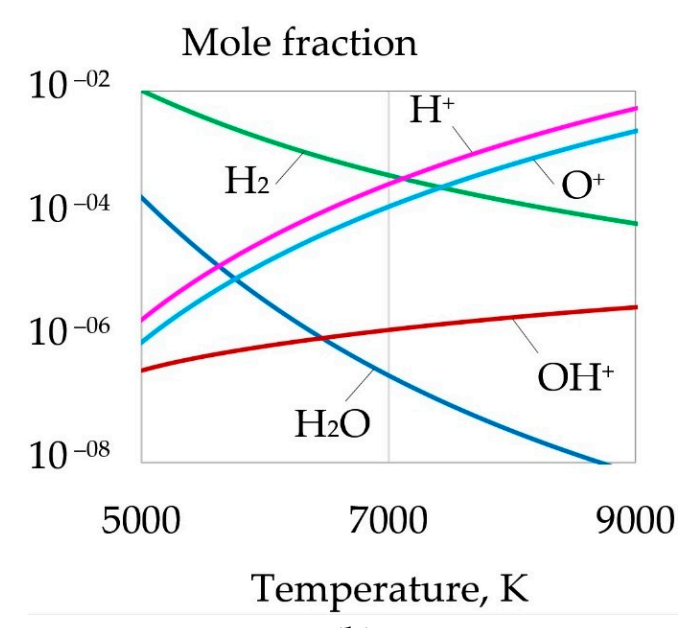

(b)

Figure 6. Molar fraction of components during dissociation of $\mathrm{H}_{2} \mathrm{O}$ : (a) up to $5000 \mathrm{~K}$; (b) at 5000-9000 K. Pressure in the system is $0.1 \mathrm{MPa}$.

Dissociation of water during underwater welding leads to an increase in the hydrogen partial pressure and oxidation of iron and alloying elements $\mathrm{Mn}, \mathrm{Si}, \mathrm{Cr}$, Ni, etc. The increase in oxidation is dependent on the pressure in the gas system. Particularly active in reactions with liquid metals are the $\mathrm{OH}$ hydroxyl group, which is formed in the arc during dissociation of $\mathrm{H}_{2} \mathrm{O}$, and water vapor, which is formed by alloying elements by reactions, as shown in Figure 7.

$$
\begin{gathered}
\mathrm{Me}+\mathrm{OH}=\mathrm{MeO}+0.5 \mathrm{H}_{2}(\text { for } \mathrm{Mn}, \mathrm{Fe}, \mathrm{Co}) \\
2 \mathrm{Me}+3 \mathrm{OH}=\mathrm{Me}_{2} \mathrm{O}_{3}+1.5 \mathrm{H}_{2}(\text { for } \mathrm{Fe}, \mathrm{Cr}, \mathrm{Al}) \\
3 \mathrm{Fe}+4 \mathrm{OH}=\mathrm{Fe}_{3} \mathrm{O}_{4}+2 \mathrm{H}_{2} \\
\mathrm{Me}+2 \mathrm{OH}=\mathrm{MeO}_{2}+\mathrm{H}_{2}(\text { for Ti, Si) }
\end{gathered}
$$




$$
\begin{gathered}
\mathrm{Me}+\mathrm{H}_{2} \mathrm{O}=\mathrm{MeO}+\mathrm{H}_{2}(\text { for } \mathrm{Mn}, \mathrm{Fe}) \\
2 \mathrm{Me}+3 \mathrm{H}_{2} \mathrm{O}=\mathrm{Me}_{2} \mathrm{O}_{3}+3 \mathrm{H}_{2}(\text { for } \mathrm{Fe}, \mathrm{Cr}, \mathrm{Al}) \\
3 \mathrm{Fe}+4 \mathrm{H}_{2} \mathrm{O}=\mathrm{Fe}_{3} \mathrm{O}_{4}+4 \mathrm{H}_{2} \\
\mathrm{Me}+2 \mathrm{H}_{2} \mathrm{O}=\mathrm{MeO}_{2}+2 \mathrm{H}_{2}(\text { for Ti, } \mathrm{Si}) .
\end{gathered}
$$

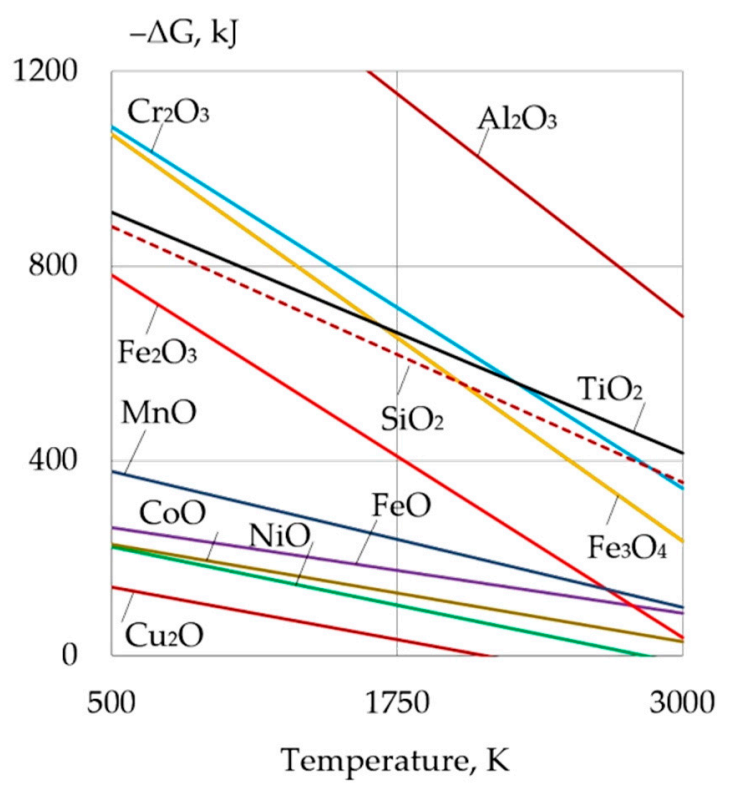

(a)

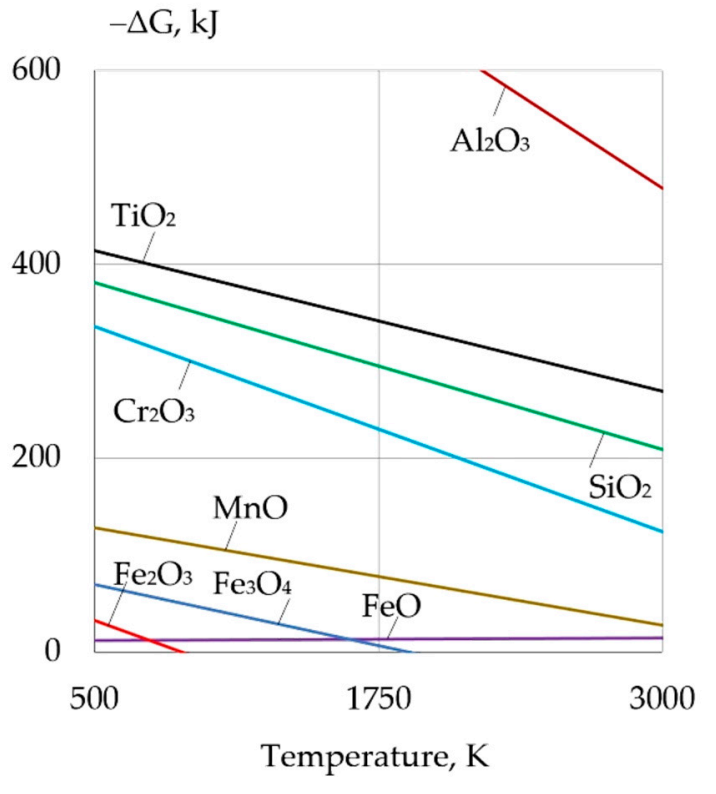

(b)

Figure 7. Gibbs free energy of metal oxidation reactions: (a) for the OH hydroxyl group; (b) for water vapor $\mathrm{H}_{2} \mathrm{O}$.

The following elements are particularly active in oxidation reactions with hydroxyl: Al $\left(\Delta G_{500 K}=-1611.9 \mathrm{~kJ}\right), \mathrm{Cr}\left(\Delta \mathrm{G}_{500 \mathrm{~K}}=-1086.5 \mathrm{~kJ}\right), \mathrm{Ti}\left(\Delta \mathrm{G}_{500 \mathrm{~K}}=-911.4 \mathrm{~kJ}\right), \mathrm{Fe}$ in $\mathrm{Fe}_{3} \mathrm{O}_{4}$ $\left(\Delta \mathrm{G}_{500 \mathrm{~K}}=-1070 \mathrm{~kJ}\right)$, and $\mathrm{Fe}_{2} \mathrm{O}_{3}\left(\Delta \mathrm{G}_{500 \mathrm{~K}}=-782 \mathrm{~kJ}\right)$. Resistance to oxidation by water vapor is shown by $\mathrm{Ni}\left(\Delta \mathrm{G}_{500 \mathrm{~K}}=+26 \mathrm{~kJ}\right), \mathrm{Cu}$ for $\mathrm{Cu}_{2} \mathrm{O}\left(\Delta \mathrm{G}_{500 \mathrm{~K}}=+86 \mathrm{~kJ}\right)$, and $\mathrm{Co}\left(\Delta \mathrm{G}_{500 \mathrm{~K}}=+20.3 \mathrm{~kJ}\right)$.

Thermodynamic modeling of phase equilibria shows that adding $20 \% \mathrm{CaF}_{2}$ and $20 \% \mathrm{Na}_{3} \mathrm{AlF}_{6}$ into the gas system at $0.1 \mathrm{MPa}$ and at $0.6 \mathrm{MPa}$ leads to a decrease in the partial pressure of $\mathrm{H}, \mathrm{H}_{2}$, and the $\mathrm{OH}$ hydroxyl group due to the formation of HF, as shown in Figure 8.

For example, at $3000 \mathrm{~K}$ at a pressure of $0.1 \mathrm{MPa}$ with $20 \% \mathrm{CaF}_{2}$ added, the partial pressure of $\mathrm{H}_{2}$, $\mathrm{OH}$, and $\mathrm{O}$ decreases by $9.1,8.7$, and $3.2 \%$, respectively, and with $20 \% \mathrm{Na}_{3} \mathrm{AlF}_{6}$ added, the partial pressure of $\mathrm{H}_{2}, \mathrm{OH}$, and $\mathrm{O}$ decreases by $15.8,9.8$, and $3.16 \%$, respectively. At the pressure of $0.6 \mathrm{MPa}$ at $3000 \mathrm{~K}$, adding $20 \% \mathrm{CaF}_{2}$ reduces the partial pressure of $\mathrm{H}_{2}, \mathrm{OH}$, and $\mathrm{O}$ by $7.8,8.57$, and $4.4 \%$, respectively, and adding $20 \% \mathrm{Na}_{3} \mathrm{AlF}_{6}$ reduces the partial pressure of $\mathrm{H}_{2}, \mathrm{OH}$, and $\mathrm{O}_{2}$ by $15.68,8.57$, and $0.15 \%$, respectively. Adding $\mathrm{CaF}_{2}$ and $\mathrm{Na}_{3} \mathrm{AlF}_{6}$ leads to the formation of $\mathrm{HF}$ with a partial pressure of up to 0.01 and $0.058 \mathrm{MPa}$, respectively, at a system pressure of $0.1 \mathrm{MPa}$ and $0.6 \mathrm{MPa}$. 


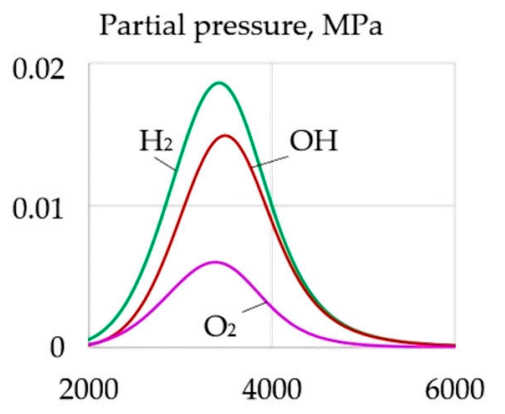

Temperature, $\mathrm{K}$

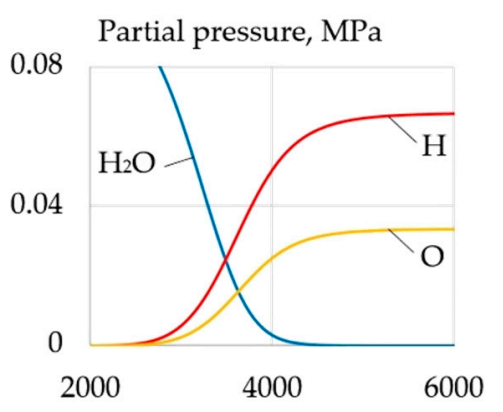

Temperature, $\mathrm{K}$

(a)

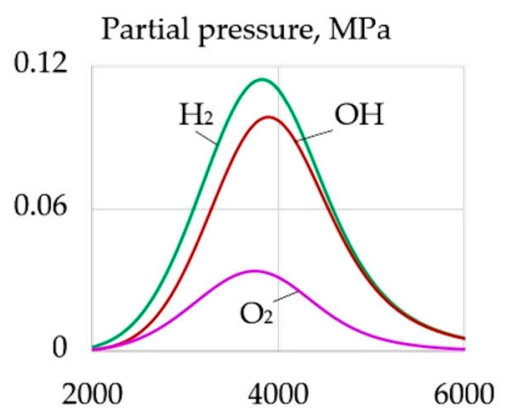

Temperature, $\mathrm{K}$

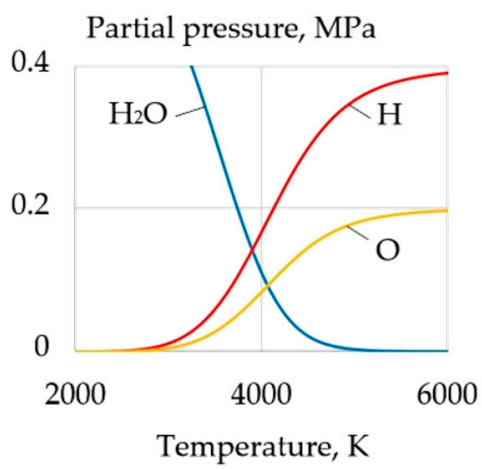

(d)
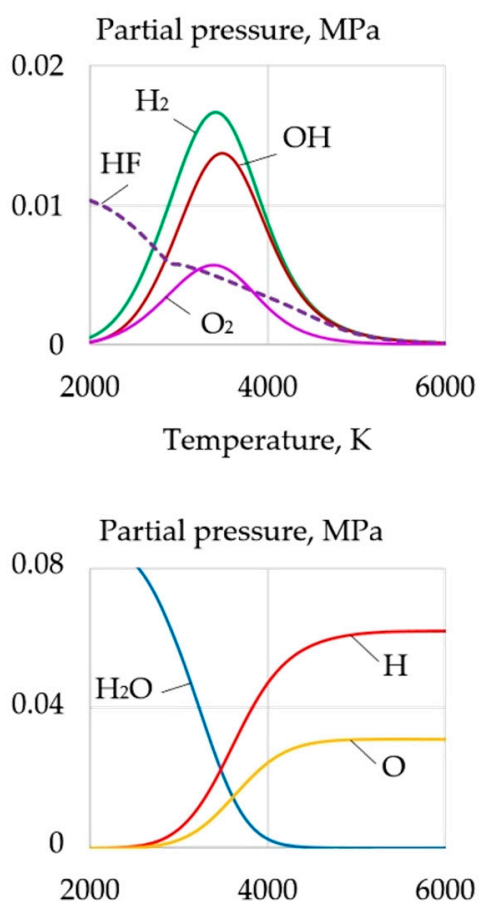

Temperature, $\mathrm{K}$

(b)

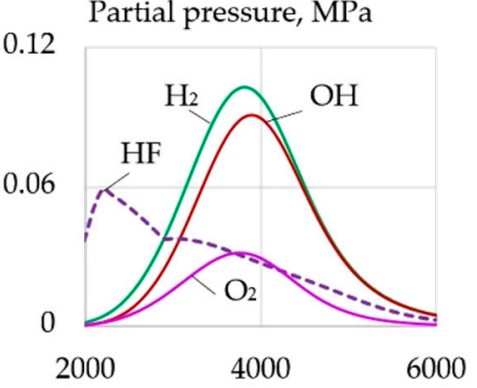

Temperature, $\mathrm{K}$

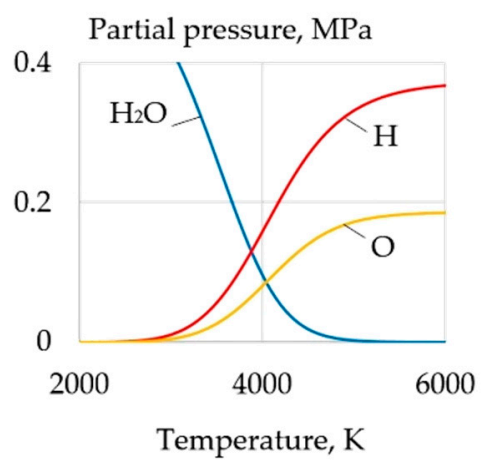

(e)
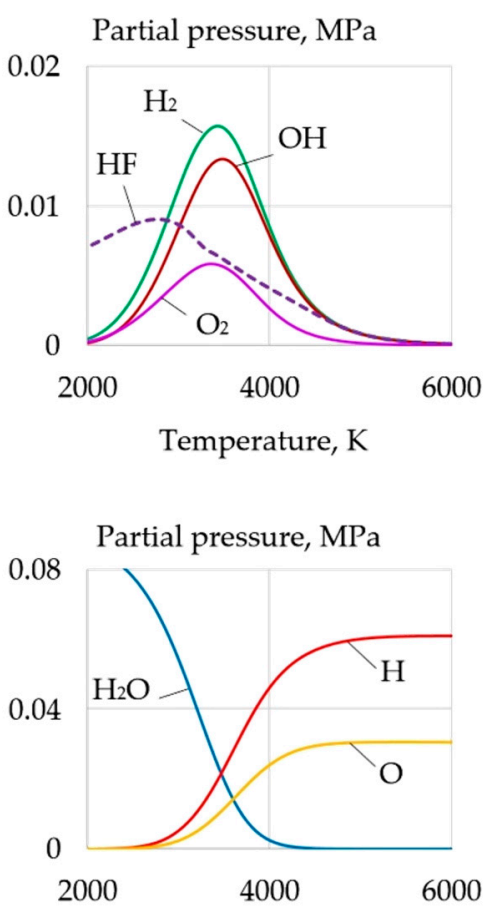

Temperature, $\mathrm{K}$

(c)
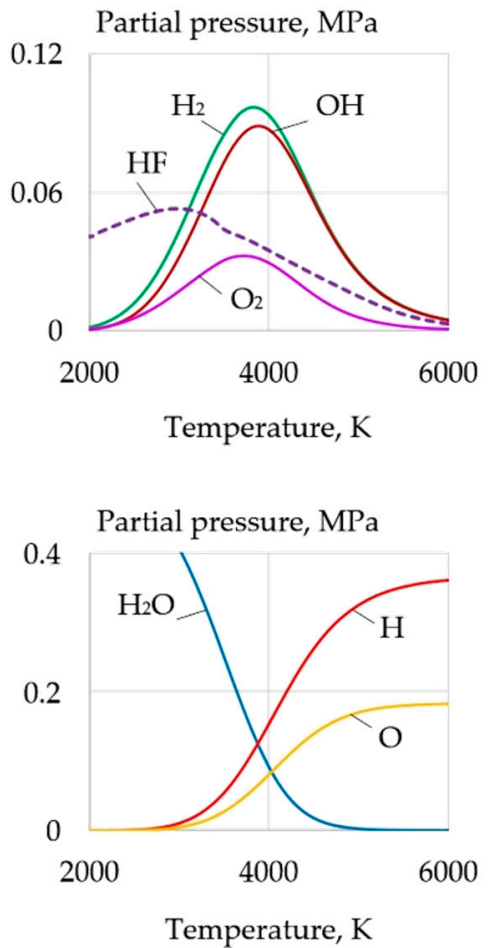

(f)

Figure 8. Change in partial pressure of components in the equilibrium gas mixture in the vapor-gas bubble at $0.1 \mathrm{MPa}(\mathbf{a}-\mathbf{c})$ and at $0.6 \mathrm{MPa}(\mathbf{d}-\mathbf{f}): \mathbf{a}, \mathbf{d}-100 \% \mathrm{H}_{2} \mathrm{O} ; \mathbf{b}, \mathbf{e}-$ when adding $20 \% \mathrm{CaF}_{2} ; \mathbf{c}, \mathbf{f}-$ when adding $20 \% \mathrm{Na}_{3} \mathrm{AlF}_{6}$.

During heating, the complex fluoride $\mathrm{Na}_{3} \mathrm{AlF}_{6}$ in the arc dissociates with the formation of $\mathrm{NaF}$ and $\mathrm{AlF}_{3}$. Evaporation and dissociation of $\mathrm{CaF}_{2}$ and $\mathrm{Na}_{3} \mathrm{AlF}_{6}$ leads to the formation of $\mathrm{NaF}, \mathrm{AlF}_{3}, \mathrm{AlF}_{2}$, 
$\mathrm{AlF}$, and $\mathrm{CaF}$ molecules, which reduce the partial pressure of $\mathrm{H}_{2}$ in the vapor-gas bubble and react with $\mathrm{H}_{2} \mathrm{O}$ and $\mathrm{H}_{2}$ according to reactions shown in Figure 9:

$$
\begin{gathered}
1.5 \mathrm{H}_{2} \mathrm{O}+\mathrm{AlF}_{3}=0.5 \mathrm{Al}_{2} \mathrm{O}_{3}+3 \mathrm{HF} \\
\mathrm{H}_{2} \mathrm{O}+\mathrm{CaF}_{2}=\mathrm{CaO}+2 \mathrm{HF} \\
0.5 \mathrm{H}_{2}+\mathrm{NaF}=\mathrm{Na}+\mathrm{HF} \\
1.5 \mathrm{H}_{2}+\mathrm{AlF}_{3}=\mathrm{Al}+3 \mathrm{HF} \\
\mathrm{H}+\mathrm{F}=\mathrm{HF} \\
0.5 \mathrm{H}_{2}+\mathrm{F}=\mathrm{HF}
\end{gathered}
$$

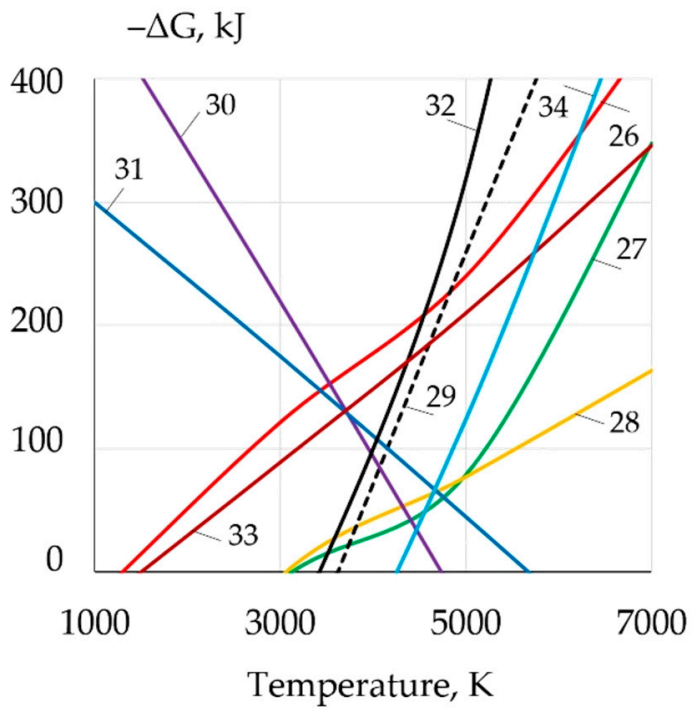

(a)

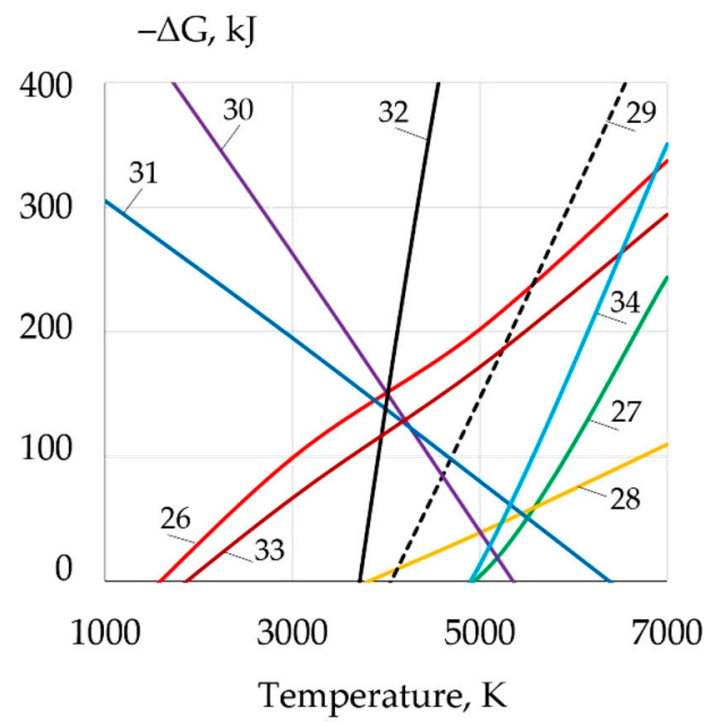

(b)

Figure 9. Gibbs free energy of reactions (26)-(34) of interaction of fluorides and fluorine in a vapor-gas bubble atmosphere at $0.1 \mathrm{MPa}(\mathbf{a})$ and at $0.6 \mathrm{MPa}(\mathbf{b})$.

At high temperatures in the arc, metallurgical reactions occur in the gas phase between the fluorides $\mathrm{NaF}, \mathrm{AlF}_{3}, \mathrm{AlF}_{2}$, and $\mathrm{AlF}$ and the oxide $\mathrm{TiO}_{2}$ with the formation of fluorides $\mathrm{TiF}_{3}, \mathrm{TiF}_{4}$, and $\mathrm{TiF}_{2}$, which are highly reactive to $\mathrm{H}_{2} \mathrm{O}$ and $\mathrm{H}_{2}$, for example, in reactions (32)-(34), as shown in Figure 9.

$$
\begin{gathered}
4 \mathrm{TiO}_{2}+2 \mathrm{Na}_{3} \mathrm{AlF}_{6}=4 \mathrm{TiF}_{3}+3 \mathrm{Na}_{2} \mathrm{O}+\mathrm{Al}_{2} \mathrm{O}_{3}+\mathrm{O}_{2} \\
1.5 \mathrm{H}_{2} \mathrm{O}+\mathrm{TiF}_{3}=0.5 \mathrm{Ti}_{2} \mathrm{O}_{3}+3 \mathrm{HF} \\
1.5 \mathrm{H}_{2}+\mathrm{TiF}_{3}=\mathrm{Ti}+3 \mathrm{HF}
\end{gathered}
$$

In a $\mathrm{TiO}_{2}-\mathrm{Fe}_{2} \mathrm{O}_{3}$ slag system with $10 \% \mathrm{H}_{2}$, an increase in the content of the basic oxide $\mathrm{Fe}_{2} \mathrm{O}_{3}$ to $30 \%$ and a decrease in the acidic oxide $\mathrm{TiO}_{2}$ to $70 \%$ results in an increase in the mass fraction of $\mathrm{H}_{2} \mathrm{O}$, especially at the melting temperature of $1700-1750 \mathrm{~K}$. When adding a mixture of fluorides $\left(\mathrm{CaF}_{2}+\mathrm{Na}_{3} \mathrm{AlF}_{6}\right)$ of up to $30 \%$ into the $\mathrm{TiO}_{2}-\mathrm{CaF}_{2}-\mathrm{Na}_{3} \mathrm{AlF}_{6}$ slag system, a sharp decrease occurs in the mass fraction of $\mathrm{H}_{2} \mathrm{O}$ in the slag, especially at the melting temperature of $1350-1550 \mathrm{~K}$. A decrease in the $\mathrm{H}_{2} \mathrm{O}$ fraction with an increase in the fluorides content can be explained by the formation of HF and $\mathrm{TiF}_{3}$, which confirms the possibility of reactions (32)-(34) in the slag phase, as shown in Figure 10. 


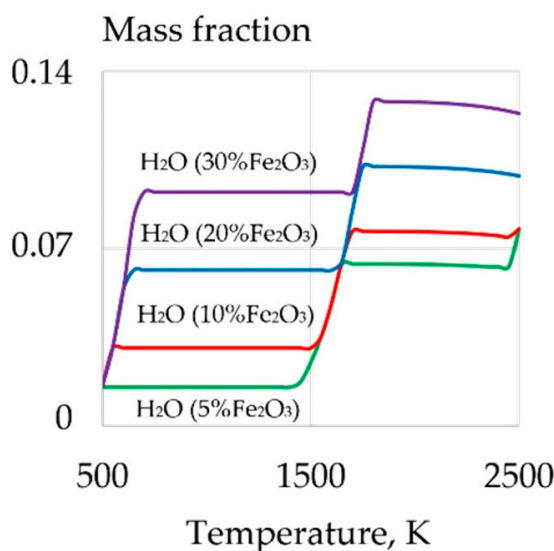

(a)

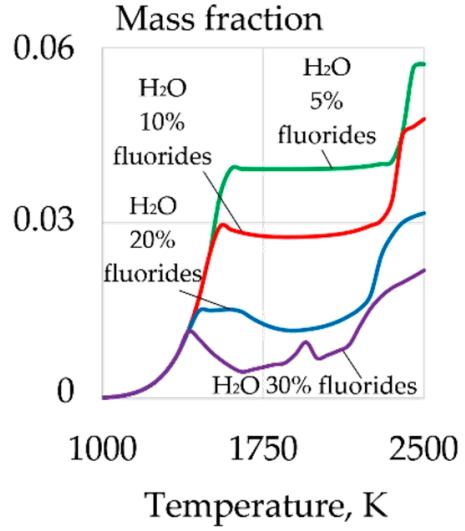

(b)

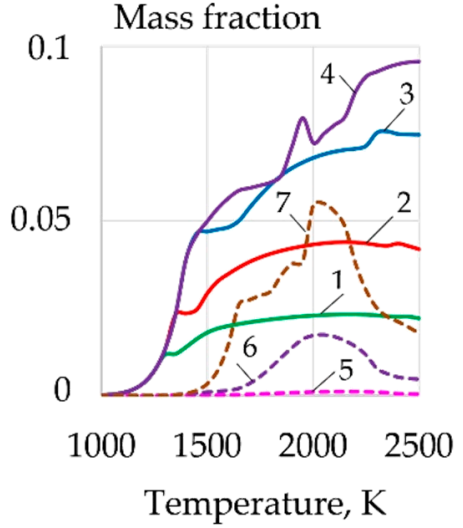

(c)

Figure 10. Mass fraction of water vapor $\mathrm{H}_{2} \mathrm{O}$ and fluorides in an equilibrium slag system when adding $10 \% \mathrm{H}_{2}$ : (a) $\mathrm{H}_{2} \mathrm{O}$ content in the $\mathrm{TiO}_{2}-\mathrm{Fe}_{2} \mathrm{O}_{3}$ slag with a $\mathrm{Fe}_{2} \mathrm{O}_{3}$ content of 5-30\%; (b) $\mathrm{H}_{2} \mathrm{O}$ content in the $\mathrm{TiO}_{2}-\mathrm{CaF}_{2}-\mathrm{Na}_{3} \mathrm{AlF}_{6}$ slag with fluoride $\left(\mathrm{CaF}_{2}-\mathrm{Na}_{3} \mathrm{AlF}_{6}\right)$ content of $5-30 \%$; (c) $\mathrm{HF}, \mathrm{TiF}_{3}$ content in $\mathrm{TiO}_{2}-\mathrm{CaF}_{2}-\mathrm{Na}_{3} \mathrm{AlF}_{6}$ slag with fluoride $\left(\mathrm{CaF}_{2}-\mathrm{Na}_{3} \mathrm{AlF}_{6}\right)$ content of 5-30\%: 1- HF for 5\% fluorides; 2-HF for $10 \%$ fluorides; 3 - HF for $20 \%$ fluorides; 4 - HF for $30 \%$ fluorides; 5 - $\mathrm{TiF}_{3}$ for $10 \%$ fluorides; $6-\mathrm{TiF}_{3}$ for $20 \%$ fluorides; $7-\mathrm{TiF}_{3}$ for $30 \%$ fluorides.

Testing of flux-cored wires with gas-slag systems $\mathrm{TiO}_{2}-\mathrm{Fe}_{2} \mathrm{O}_{3}$ and $\mathrm{TiO}_{2}-\mathrm{CaF}_{2}-\mathrm{Na}_{3} \mathrm{AlF}_{6}$ showed that the presence of $\mathrm{Fe}_{2} \mathrm{O}_{3}$ can lead to the formation of slag inclusions and penetration defects. Utilization of a $\mathrm{TiO}_{2}-\mathrm{CaF}_{2}-\mathrm{Na}_{3} \mathrm{AlF}_{6}$ gas-slag system provided a higher density of deposited metal and a decrease in porosity and slag inclusions, as shown in Figure 11.

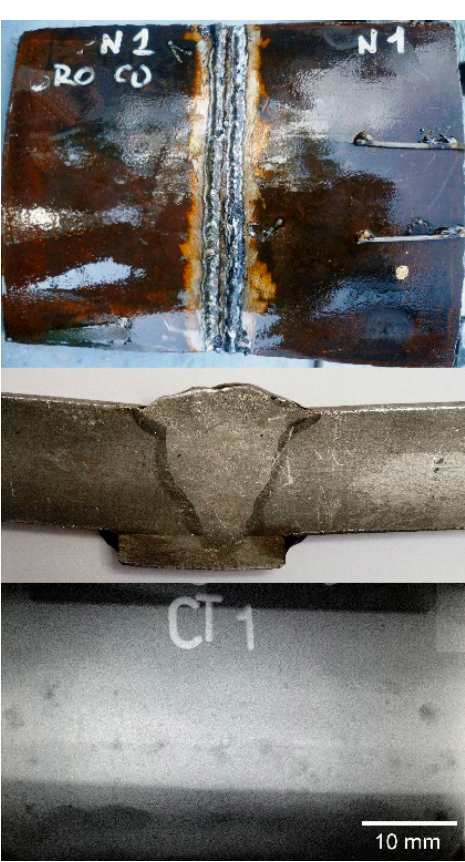

(a)

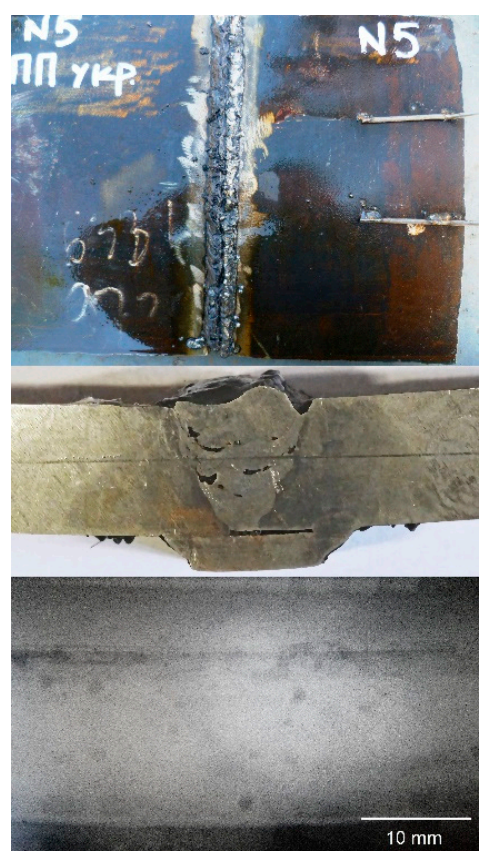

(b)

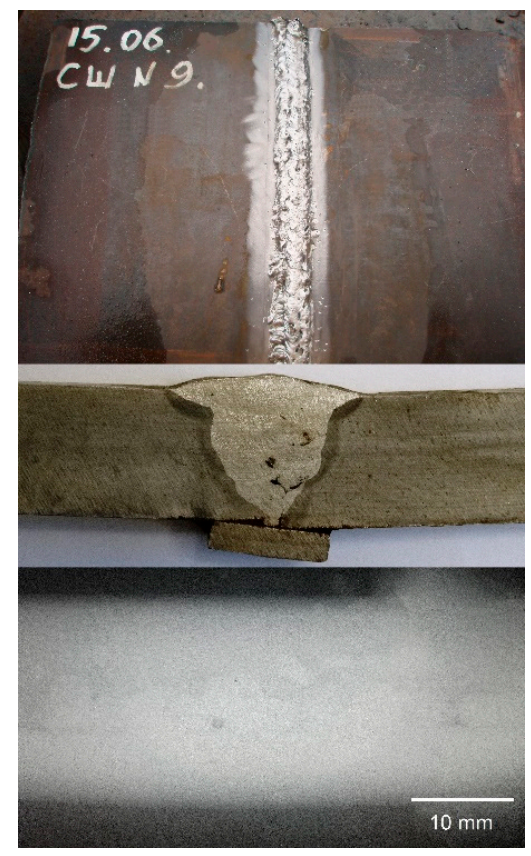

(c)

Figure 11. View of welds, macrostructure, and X-ray testing: (a) UW/CS-1 coated electrode; (b) PPS-AN1 flux-cored wire; (c) PPS-APL2 flux-cored wire.

The chemical composition and mechanical properties of the welds are shown in Tables 2 and 3. 
Table 2. Chemical composition of steel and deposited metal in underwater wet welding of API X70 steel, wt.\%.

\begin{tabular}{ccccccc}
\hline Material & $\mathbf{C}$ & $\mathbf{S i}$ & $\mathbf{M n}$ & $\mathbf{N i}$ & $\mathbf{S}$ & $\mathbf{P}$ \\
\hline API X70 steel & $0.1-0.12$ & $0.29-0.31$ & $1.7-1.75$ & $0.015-0.02$ & $>0.006$ & $>0.013$ \\
\hline UW/CS-1 electrode & $0.06-0.1$ & $0.3-0.35$ & $0.49-0.65$ & - & $>0.008$ & $>0.017$ \\
\hline PPS-AN1 flux-cored wire & $0.04-0.12$ & $>0.002$ & $0.048-0.12$ & $1.1-1.47$ & $>0.013$ & $>0.018$ \\
\hline PPS-APL2 flux-cored wire & $0.03-0.15$ & $>0.018$ & $0.27-0.52$ & $0.8-1.2$ & $>0.013$ & $>0.015$ \\
\hline
\end{tabular}

Table 3. Mechanical properties of underwater wet welding welds of API X70 steel.

\begin{tabular}{|c|c|c|c|c|c|}
\hline $\begin{array}{c}\text { Welding } \\
\text { Consumables }\end{array}$ & $\begin{array}{c}\text { Yield Strength, } \\
\mathrm{MPa}\end{array}$ & $\begin{array}{c}\text { Tensile } \\
\text { Strength, MPa }\end{array}$ & Elongation, \% & $\begin{array}{c}\text { Impact Toughness, } \\
\mathrm{KCV}_{+20}, \mathrm{~J}\end{array}$ & $\begin{array}{c}\text { Weld } \\
\text { Hardness, } \mathrm{HV}_{5}\end{array}$ \\
\hline UW/CS-1 electrode & $440-468$ & $498-545$ & $6-12$ & $68-89$ & $165-203$ \\
\hline $\begin{array}{c}\text { PPS-AN1 } \\
\text { flux-cored wire }\end{array}$ & $323-336$ & $371-458$ & $2-11.2$ & $62-73$ & 135-212 \\
\hline $\begin{array}{c}\text { PPS-APL2 } \\
\text { flux-cored wire }\end{array}$ & $330-356$ & $433-462$ & $4-12.6$ & $67-98$ & $162-200$ \\
\hline
\end{tabular}

Due to oxidation, the content of alloying elements, especially manganese and carbon, significantly decreased in the direction from the root to the cap weld. The lowest transition coefficient for alloying elements was observed when welding with flux-cored wire PPS-AN1, as shown in Figure 12.

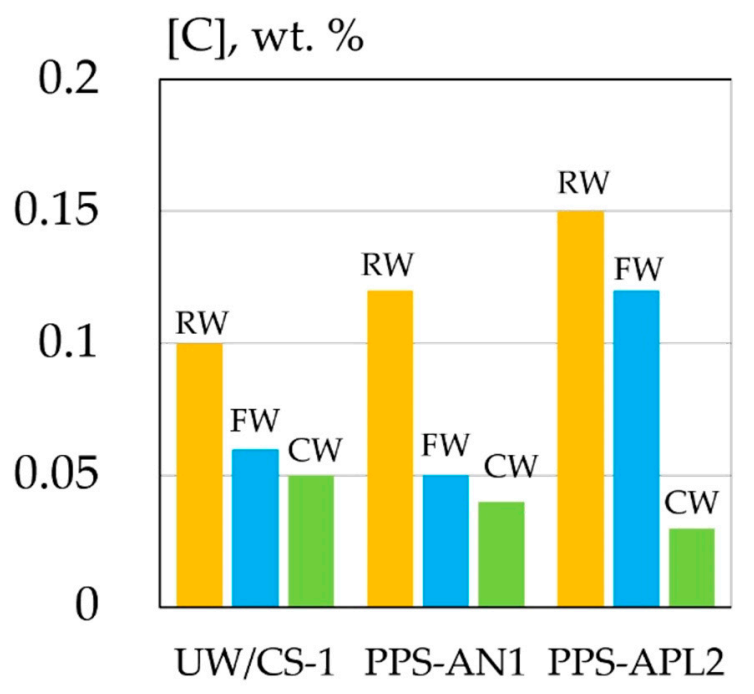

(a)

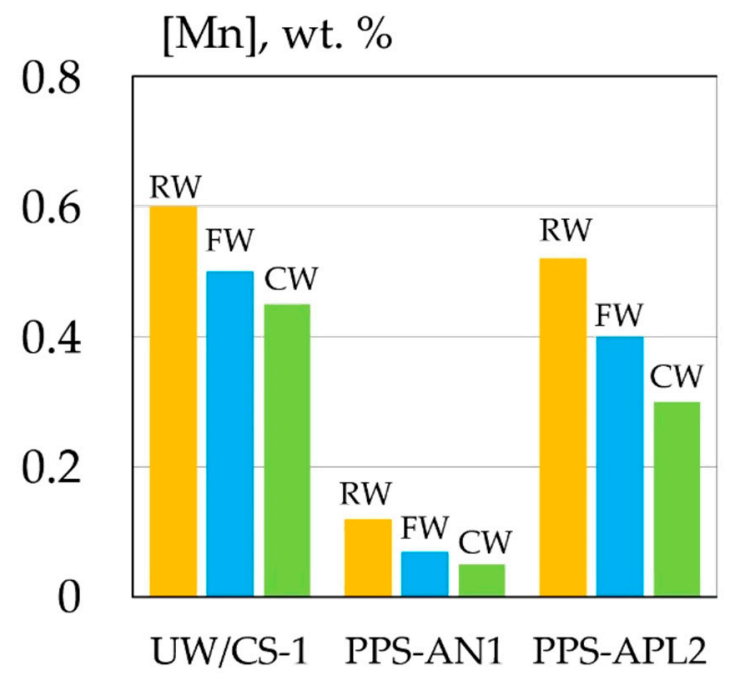

(b)

Figure 12. Change in the content of (a) carbon and (b) manganese in different weld zones when welding with the coated electrode UW/CS-1 and flux-cored wires PPS-AN1 and PPS-APL2: RW-root weld; FW-fill weld; CW-cap weld.

Mechanical tests showed that welds made with the flux-cored wire PPS-APL2 have similar characteristics as regards impact toughness, ductility, and hardness as welds made with the coated electrode UW/CS-1; however, the ultimate strength of the welds is $13-15 \%$ lower, as shown in Table 3 and in Figure 13. 


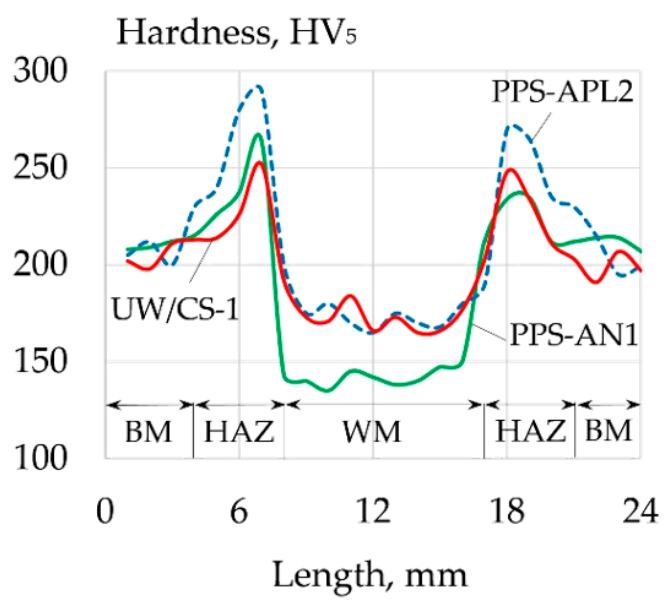

(a)

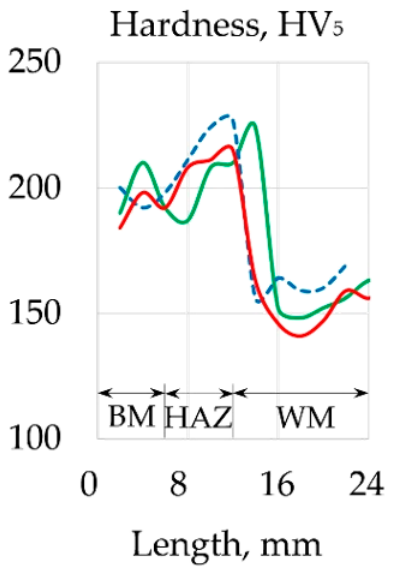

(b)

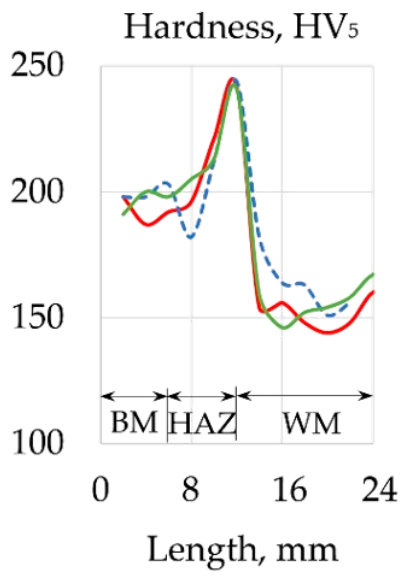

(c)

Figure 13. Hardness in the cross section: (a) butt welds; (b) lap welds with PPS-AN1 flux-cored wire; (c) lap welds with PPS-APL2 flux-cored wire. BM-base metal; HAZ—heat-affected zone; WM-weld metal.

Welds made with the flux-cored wire PPS-AN1 had poorer mechanical characteristics because of the presence of elongated slag inclusions, as shown in Figure 14.

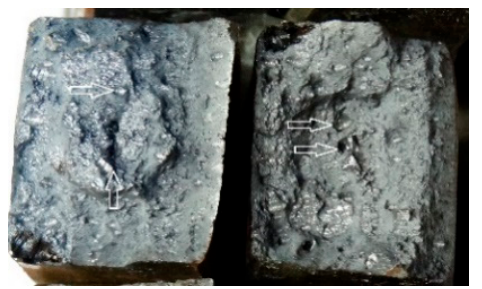

(a)

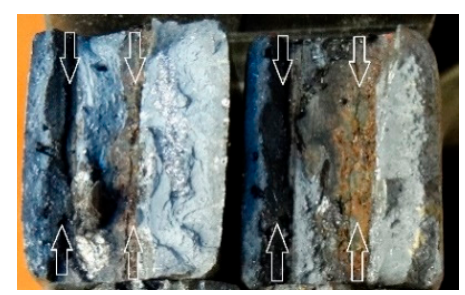

(b)

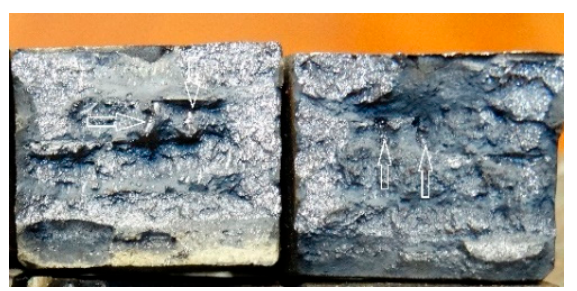

(c)

Figure 14. Welds fractures after tensile tests: (a) UW/CS-1 coated electrode; (b) PPS-AN1 flux-cored wire; (c) PPS-APL2 flux-cored wire. Arrows indicate slag inclusions.

Welds made with the coated electrode UW/CS-1 and flux-cored wire PPS-APL2 had the highest density and a small number of small non-metallic inclusions, as shown in Figures 15 and 16.

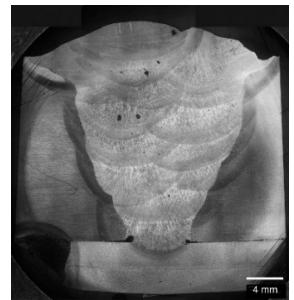

(a)

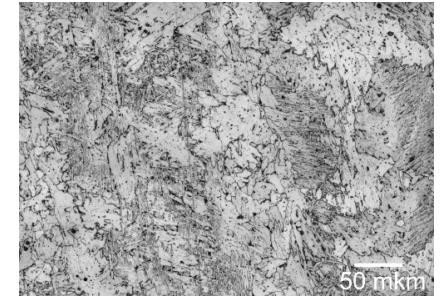

(b)

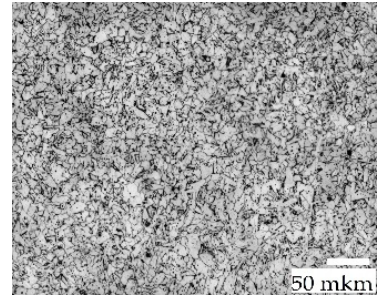

(c)

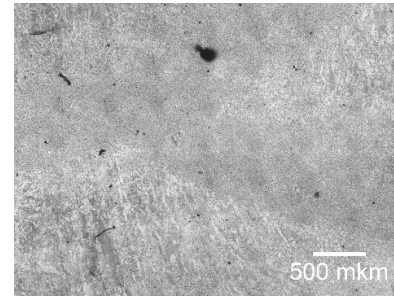

(d)

Figure 15. A butt joint when welding with the coated electrode UW/CS-1: (a) macrostructure of the weld; (b) microstructure of the primary ferrite; (c) microstructure of the ferrite with second phase; (d) typical non-metallic inclusions in the center of the weld. Microstructure of the weld center. 


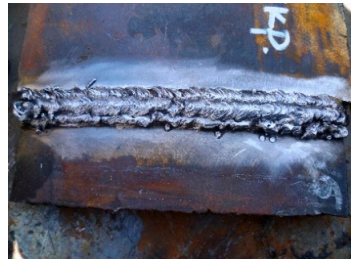

(a)

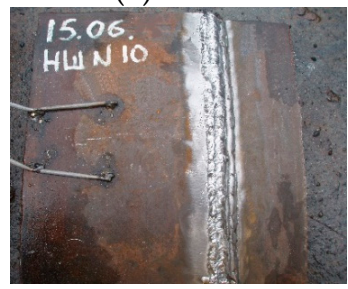

(e)

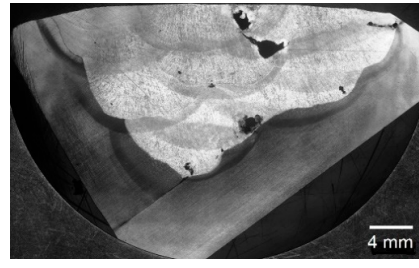

(b)

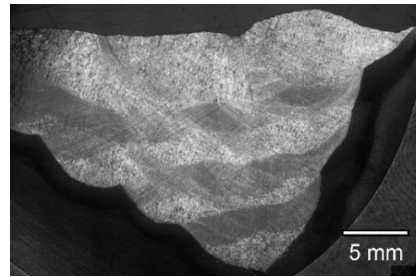

(f)

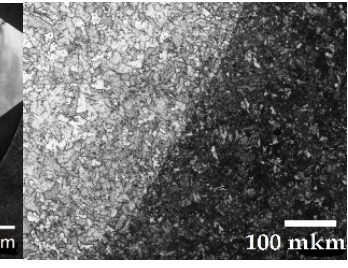

(c)

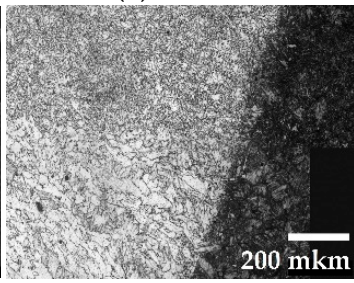

(g)

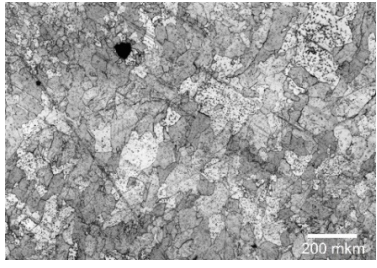

(d)

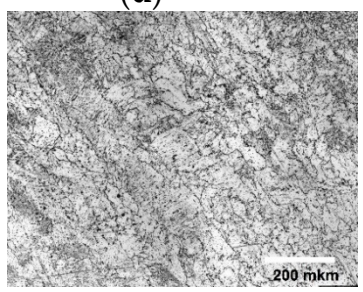

(h)

Figure 16. A lap joints when welding with PPS-AN1 (a-d) and PPS-APL2 (e-h) flux-cored wires: (a,e) view of lap joints; $(\mathbf{b}, \mathbf{f})$ weld macrostructure; $(\mathbf{c}, \mathbf{g})$ macrostructure of the fusion zone; $(\mathbf{d}, \mathbf{h})$ microstructure of the primary ferrite. Microstructure of the weld center.

To determine the content of diffusible hydrogen, measurements were performed by vacuum method at a pressure of $1.5 \mathrm{~Pa}$ for $72 \mathrm{~h}$ for bead welding of $100 \mathrm{~mm} \times 25 \mathrm{~mm} \times 8 \mathrm{~mm}$ samples with flux-cored wires PPS-AN1 for the $\mathrm{TiO}_{2}-\mathrm{Fe}_{2} \mathrm{O}_{3}$ system and PPS-APL2 for the TiO $-\mathrm{CaF}_{2}-\mathrm{Na}_{3} \mathrm{AlF}_{6}$ system. Under identical welding conditions, the average content of $[\mathrm{H}]$ with the PPS-AN1 wire was $34.8 \mathrm{~mL} / 100 \mathrm{~g}$, and with the PPS-APL2 wire, $27.1 \mathrm{~mL} / 100 \mathrm{~g}$, i.e., a decrease of $21.1 \%$, as shown in Figure 17.

$$
[\mathrm{H}], \mathrm{ml} / 100 \mathrm{~g}
$$

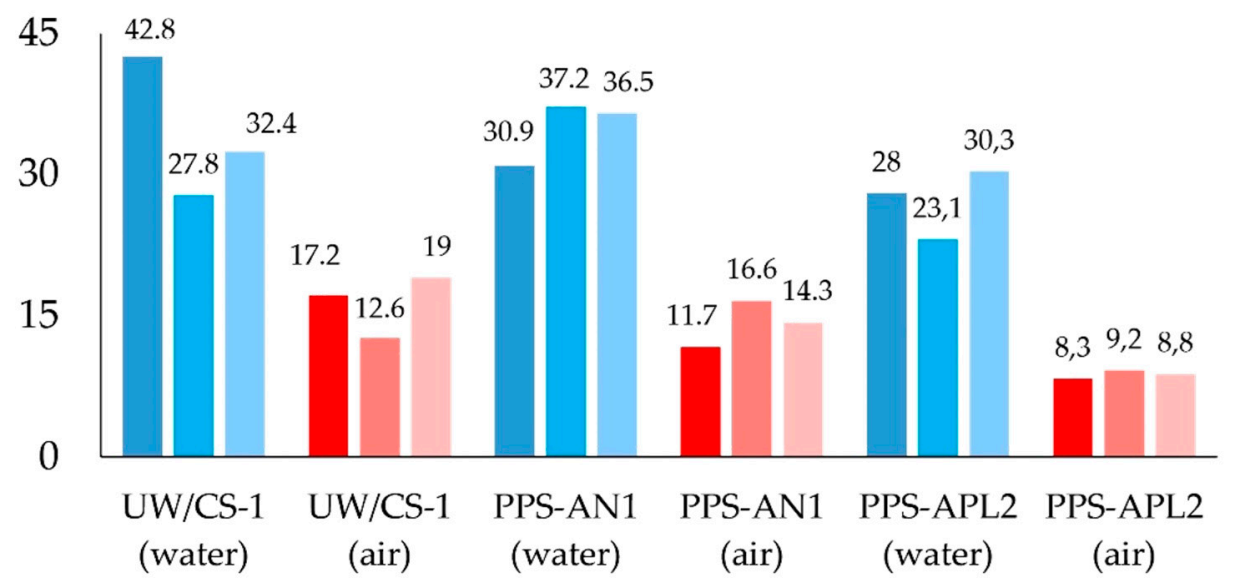

Figure 17. Content of diffusible hydrogen during welding with the electrodes UW/CS-1, the flux-cored wires PPS-AN1, and PPS-APL2 in air and under water.

\section{Conclusions}

(1) This work proposed a model of metallurgical and electrochemical processes in underwater wet welding in a vapor-gas bubble, molten slag, and liquid weld pool based on a thermodynamic modeling for the optimization of the gas-slag system and the improvement of the quality of welds. Thermodynamic modeling and experiments showed that a complex mechanism based on reducing the partial pressure of $\mathrm{H}_{2} \mathrm{O}, \mathrm{H}_{2}, \mathrm{H}$, and $\mathrm{OH}$ in the atmosphere of the arc and in the vapor-gas bubble and increasing the hydroxyl capacity of the basic slag system can be used to reduce the diffusible hydrogen content and slag inclusions in underwater wet welding of high-strength 
steel. This solution is achieved by increasing the metallurgical activity of the gas-slag system in removal of water vapor, hydrogen, and hydroxyl in reactions with the formation of HF and ionic dissolution of water vapor in the form of hydroxyl groups $\mathrm{OH}$ in the basic fluorine-containing slag of the $\mathrm{TiO}_{2}-\mathrm{CaF}_{2}-\mathrm{Na}_{3} \mathrm{AlF}_{6}$ system of the flux-cored wire.

(2) The oxidizing potential of the atmosphere of the arc and the vapor-gas bubble decreases with an increase in fluorides, which improves the transition coefficient of the alloying elements and the density of the deposited metal and reduces the volume of slag inclusions. As a result of using a flux-cored wire with a $\mathrm{TiO}_{2}-\mathrm{CaF}_{2}-\mathrm{Na}_{3} \mathrm{AlF}_{6}$ system, the average strength and impact toughness of the weld increased by 8 and $22 \%$, respectively, and the diffusible hydrogen content decreased by $21 \%$ compared to a flux-cored wire with a $\mathrm{TiO}_{2}-\mathrm{Fe}_{2} \mathrm{O}_{3}$ system.

Author Contributions: Conceptualization, modelling and analysis, S.G.P.; methodology, administration, A.M.L.; investigation, A.S.M. All authors have read and agreed to the published version of the manuscript.

Funding: This research was supported by the project "Energy-efficient systems based on renewable energy for Arctic conditions" (EFREA), KS1054, South-East Finland-Russia CBC Programme 2014-2020.

Acknowledgments: The authors acknowledge Peter Jones from LAB University of Applied Sciences of Lappeenranta for the technical support for preparation of the manuscript.

Conflicts of Interest: The authors declare no conflict of interest.

\section{References}

1. Çolak, Z.; Ayan, Y.; Kahraman, N. Weld morphology and mechanical performance of marine structural steel welded underwater in a real marine environment. Int. J. Adv. Manuf. Technol. 2020, 109, 491-501. [CrossRef]

2. Surojo, E.; Putri, E.D.W.S.; Budiana, E.P.; Triyono. Recent developments on underwater welding of metallic material. Procedia Struct. Integr. 2020, 27, 14-21. [CrossRef]

3. ANSI/AWS D3.6M:2017. Underwater Welding Code, 6th ed.; American Welding Society: Miami, FL, USA, 2017.

4. Tomków, J.; Fydrych, D.; Rogalski, G. Role of bead sequence in underwater welding. Materials 2019, $12,3372$. [CrossRef] [PubMed]

5. Arias, R.; Bracarense, A.Q. Fatigue crack growth assessment in underwater wet welds. Weld. J. 2017, 8, 287-294.

6. Gao, W.B.; Wang, D.P.; Cheng, F.J.; Deng, C.Y.; Xu, W. Underwater wet welding for HSLA steels: Chemical composition, defects, microstructures, and mechanical properties. Acta Metall. Sin. 2015, 28, 1097-1108. [CrossRef]

7. Chen, H.; Guo, N.; Zhang, X.; Zhou, L.; Wang, G. Effect of water flow on the microstructure, mechanical performance, and cracking susceptibility of underwater wet welded Q235 and E40 steel. J. Mater. Process. Technol. 2020, 277, 103-115. [CrossRef]

8. Parshin, S.G. The Metallurgy of Underwater and Hyperbaric Welding, 1st ed.; Polytechnic University Publishing House: Saint Petersburg, Russia, 2016. (In Russian)

9. Santos, V.R.; Monteiro, M.J.; Rizzo, F.C.; Bracarense, A.Q.; Pessoa, E.C.P.; Marinho, R.R.; Vieira, L.A. Development of an oxyrutile electrode for wet welding. Weld. J. 2012, 91, 319-328.

10. Shi, Y.; Hu, Y.; Yi, Y.; Lin, S.; Li, Z. Porosity and microstructure of underwater wet FCAW of duplex stainless steel. Metallogr. Microstruct. Anal. 2017, 6, 383-389. [CrossRef]

11. Chen, H.; Guo, N.; Xu, K.; Xu, C.; Zhou, L.; Wang, G. In-situ observations of melt degassing and hydrogen removal enhanced by ultrasonics in underwater wet welding. Mater. Des. 2020, 188, 1-14. [CrossRef]

12. Yang, Q.; Han, Y.; Jia, C.; Wu, J.; Dong, S.; Wu, C. Impeding effect of bubbles on metal transfer in underwater wet FCAW. J. Manuf. Process. 2019, 45, 682-689. [CrossRef]

13. Wang, J.; Sun, Q.; Zhang, T.; Xu, P.; Feng, J. Experimental study of arc bubble growth and detachment from underwater wet FCAW. Weld. World 2019, 63, 1747-1759. [CrossRef]

14. Feng, J.; Wang, J.; Sun, Q.; Zhao, H.; Wu, L.; Xu, P. Investigation on dynamic behaviors of bubble evolution in underwater wet flux-cored arc welding. J. Manuf. Process. 2017, 28, 156-167. [CrossRef]

15. Ando, S.; Asahina, T. A study on the metallurgical properties of steel welds with underwater gravity welding. In Proceedings of the Underwater Welding International Conference, Trondheim, Norway, 27-28 June 1983. 
16. Gretsky, Y.Y.; Maksimov, S.Y.; Kravchenko, N.V. Influence of marble in rutile electrode coating on hydrogen content in weld metal during underwater welding. Autom. Weld. 1993, 7, 51-52. (In Russian)

17. Silva, W.C.D.; Bracarense, A.Q.; Pessoa, E.C.P. Effect of water depth on diffusible hydrogen on wet welds. Soldagem Inspeção 2012, 4, 298-305. [CrossRef]

18. Kirchheim, R.; Pundt, A. Hydrogen in metals. In Physical Metallurgy, 5th ed.; Laughlin, D., Hono, K., Eds.; Elsevier: Amsterdam, The Netherlands, 2014; pp. 2597-2705.

19. Chen, H.; Guo, N.; Shi, X.; Du, Y.; Feng, J.; Wang, G. Effect of hydrostatic pressure on protective bubble characteristic and weld quality in underwater flux-cored wire wet welding. J. Mater. Process. Technol. 2018, 259, 159-168. [CrossRef]

20. Kakhovs'kyi, M.Y. Influence of aqueous media on the gas saturation of weld metal in the course of underwater welding of 12KH18N10T steel. Mater. Sci. 2016, 51, 843-846. [CrossRef]

21. Klett, J.; Hecht-Linowitzki, V.; Grünzel, O.; Schmidt, E.; Maier, H.J.; Hassel, T. Effect of the water depth on the hydrogen content in SMAW wet welded joints. Springer Nat. Appl. Sci. 2020, 1269, 1-14.

22. Świerczyńska, A.; Fydrych, D.; Rogalski, G. Diffusible hydrogen management in underwater wet self-shielded flux cored arc welding. Int. J. Hydrogen Energy 2017, 42, 24532-24540. [CrossRef]

23. Fydrych, D.; Świerczyńska, A.; Rogalski, G. Effect of underwater wet welding conditions on the diffusible hydrogen content in deposited metal. Methods 2015, 11/12, 47-52.

24. Rowe, M.; Liu, S. Recent developments in underwater wet welding. Sci. Technol. Weld. Join. 2001, 6, 387-396. [CrossRef]

25. Guo, N.; Xu, C.; Du, Y.; Chen, H.; Fu, Y.; Feng, J. Influence of calcium fluoride on underwater wet welding process stability. Weld. World 2019, 63, 107-116. [CrossRef]

26. Gretsky, Y.Y.; Maksimov, S.Y.; Kravchenko, N.V. Influence of fluorite in rutile coating on hydrogen content in weld metal during underwater welding. Autom. Weld. 1993, 8, 54. (In Russian)

27. Park, J.H.; Zhang, L. Kinetic modeling of nonmetallic inclusions behavior in molten steel: A review. Metall. Mater. Trans. B 2020, 10, 1-30. [CrossRef]

28. Zhang, L.; Ren, Q.; Duan, H.; Ren, Y.; Chen, W.; Cheng, G.; Yang, W.; Sridhar, S. Modelling of non-metallic inclusions in steel. Miner. Process. Extr. Metall. 2020, 129, 1-23. [CrossRef]

29. Du Plessis, J.; Du Toit, M. Reducing diffusible hydrogen contents of shielded metal arc welds through addition of flux-oxidizing ingredients. J. Mater. Eng. Perform. 2008, 17, 50-56. [CrossRef]

30. Guo, N.; Guo, W.; Xu, C.; Du, Y.; Feng, J. Effect of boric acid concentration on viscosity of slag and property of weld metal obtained from underwater wet welding. J. Mater. Eng. Perform. 2015, 24, 2563-2568. [CrossRef]

31. Winarto, W.; Purnama, D.; Churniawan, I. The effect of different rutile electrodes on mechanical properties of underwater wet welded AH-36 steel plates. In Proceedings of the 3rd International Conference on Materials and Metallurgical Engineering and Technology ICOMMET 2017, Surabaya, Indonesia, 30-31 October 2017.

32. Jindal, S.; Mehta, N.P.; Chhibber, R. Effect of flux constituents and basicity index on mechanical properties and microstructural evolution of submerged arc welded high strength low alloy steel. Mater. Sci. Forum 2013, 739, 242-246. [CrossRef]

33. Medeiros, R.; Liu, S. A predictive electrochemical model for weld metal hydrogen pickup in underwater wet welds. J. Offshore Mech. Arct. Eng. 1998, 120, 243-248. [CrossRef]

34. Du Plessis, J.; Du Toit, M.; Pistorius, P.C. Control of diffusible weld metal hydrogen through flux chemistry modification. Weld. J. 2007, 86, 273-280.

35. Sosinsky, D.J.; Sommerville, I.D.; McLean, A. Sulphide. Phosphate. Carbonate and water capacities of metallurgical slags. Proc. Process Technol. 1986, 6, 697-703.

36. Sommerville, I.D.; Sosinsky, D.J. Solubility, Capacity and stability of species in metallurgical slags and glasses. In Pyrometallurgy for Complex Materials and Wastes; Nilmani, M., Lehner, T., Rankin, W.J., Eds.; The Minerals, Metals and Materials Society: Melbourne, Australia, 1994; pp. 73-91.

37. Allibert, M.; Gaye, H.; Geiseler, J.; Janke, D.; Keene, B.J.; Kirner, D.; Kowalski, M.; Lehmann, J.; Mills, K.C.; Neuschuetz, D.; et al. Slag Atlas, 2nd ed.; Verlag Stahleisen GmbH: Düsseldorf, Germany, 1995.

38. Khan, W.N.; Chhibber, R. Physicochemical and thermo physical characterization of $\mathrm{CaO}-\mathrm{CaF}_{2}-\mathrm{SiO}_{2}$ and $\mathrm{CaO}-\mathrm{TiO}_{2}-\mathrm{SiO}_{2}$ based electrode coating for offshore welds. Ceram. Int. 2020, 46, 8601-8614. [CrossRef]

39. Mahajan, S.; Chhibber, R. Design and development of $\mathrm{CaO}-\mathrm{SiO}_{2}-\mathrm{CaF}_{2}$ and $\mathrm{CaO}-\mathrm{SiO}_{2}-\mathrm{Al}_{2} \mathrm{O}_{3}$ based electrode coatings to weld low alloy ferritic steels for power plant applications. Ceram. Int. 2019, 45, 24154-24167. [CrossRef] 
40. Takeda, O.; Hoshino, Y.; Anbo, Y.; Yanagase, K.; Aono, M.; Sato, Y. Viscosity of molten alkaline-earth fluorides. Int. J. Thermophys. 2015, 36, 648-657. [CrossRef]

41. Dong, Y.; Jiang, Z.; Liang, L.; Li, Z. Hydrogen permeability of slags containing calcium fluoride. J. Cent. South Univ. Technol. 2011, 18, 1063-1067. [CrossRef]

42. Chung, S.H.; Sohn, I. Fundamentals of hydrogen solubility in calcium-alumino-silicate molten fluxes containing NaF. Metall. Mater. Trans. B 2019, 50B, 991-999. [CrossRef]

43. Goyenola, C.; Stafström, S.; Schmidt, S.; Hultman, L.; Gueorguiev, G.K. Carbon fluoride, CFx: Structural diversity as predicted by first principles. J. Phys. Chem. C 2014, 118, 6514-6521. [CrossRef]

44. Sajid, M.; Bai, C.; Aamir, M.; You, Z.; Yan, Z.; Lv, X. Understanding the structure and structural effects on the properties of blast furnace slag (BFS). ISIJ Int. 2019, 59, 1153-1166. [CrossRef]

45. Budau, J.H.; Paulus, B.; Steenbergen, K.G. Theoretical investigation of the crystal structure of AlOF. Chem. Phys. 2017, 491, 112-117. [CrossRef]

46. Jung, I.-H. Thermodynamic modeling of gas solubility in molten slags (II) water. ISIJ Int. 2006, 46, 1587-1593. [CrossRef]

47. Turkdogan, E.T. Fundamentals of Steelmaking, 1st ed.; The Institute of Materials: London, UK, 1996.

48. Park, J.-Y.; Chang, W.-S.; Sohn, I. Effect of $\mathrm{MnO}$ to hydrogen dissolution in $\mathrm{CaF}_{2}-\mathrm{CaO}-\mathrm{SiO}_{2}$ based welding type fluxes. Sci. Technol. Weld. Join. 2012, 17, 134-140. [CrossRef]

49. Karkhin, V.A.; Levchenko, A.M. Computer-aided determination of diffusible hydrogen in deposited weld metal. Weld. World 2008, 52, 3-11. [CrossRef]

50. Chase, M.W. NIST-JANAF Thermochemical Tables, 4th ed.; NIST: New York, NY, USA, 1998.

Publisher's Note: MDPI stays neutral with regard to jurisdictional claims in published maps and institutional affiliations. 